\title{
The Impact of Economic Factors on the Foreign Exchange Rates between USA and Four Big Emerging Countries: China, India, Brazil and Mexico
}

\author{
Nguyen Quang My \\ Alliant School of Management, Alliant International University, San Diego, USA \\ E-mail: nmy@alliant.edu \\ Mustafa Sayim \\ Alliant School of Management, Alliant International University, San Diego, USA \\ msayim2@alliant.edu
}

Received: Feb. 25, 2016

Accepted: Feb. 28, 2016

Published: Mar. 28, 2016

doi:10.5296/ifb.v3i1.9108

URL: http://dx.doi.org/10.5296/ifb.v3i1.9108

\begin{abstract}
This study examines the impact of macro-economic factors on the foreign exchange rates between USA and four big emerging countries: India, Mexico, Brazil and China for the period of 2005 to 2014. This study uses Enter and Stepwise multiple regression methods to investigate the impact of market fundamental on the exchange rates. The empirical findings reveal that the macro-economic factors significantly predict and influence the exchange rates between USD/CNY (US dollar/Chinese yuan), USD/INR (US dollar/Indian rupee), USD/BRL (US dollar/ Brazilian real), and USD/MNX (US dollar/Mexican pesos). It is crucial to emphasize that the macroeconomic policies have to be implemented in order to stabilize and reduce the exchange rates volatilities.
\end{abstract}

Keywords: Exchange rate, Emerging markets, Macro-economic factors, Enter and stepwise regression models 


\section{Introduction}

Understanding the impact of economic factors affecting on the US foreign exchange policy toward other countries is very crucial for MNCs (Multi-National Corporations), investors, and practitioners. It is widely accepted that the U.S. foreign exchange policy is an indispensable part of the U.S Monetary Policy to maintain its leading international position. As Rangarajan \& Prased (2008) stated "with an open economy and large capital inflows, management of the exchange rate becomes an independent concern." The U.S. could be regarded as the center country for the international monetary system (Dooley, Folkerts-Landau, \& Garber, 2004).

US dollar is the most accepted and commonly used currency in international trade and was considered as the dollar standard for a long period of time (Haberler, 1972; Genberg \& Swoboda, 1977; Ross, 1983; McMichael, 1996; McKinnon \& Schnabl, 2003; Devereux, Shi \& Xu, 2007; Chunwei, 2008; Bracke \& Bunda, 2011). According to the Bank for International Settlements, $86 \%$ of all foreign exchange transactions that took place in the month of April 2007 were against the U.S. dollar. Besides, the U.S. dollar is still the world's reserve currency even though it is no longer backed by gold. Additionally, US dollar could be considered as the worldwide instrument to report currency and monetary by international banks and countries (Laurent, 1974; Avery et al., 1987; Porter \& Judson, 1996; Feige, 1996; Orphanides \& Porter, 2000; Eichengreen, 2000). Virtually all interbank transactions, by market participants domestic and abroad, involve a purchase or sale of dollars for a foreign currency (Kubarych, 1983). Ehrmann, Fratzscher, \& Rigobon (2011) underlined "the dominance of US markets as the main driver of global financial markets: US financial markets explain, on average, more than $25 \%$ of movements in euro area financial markets, whereas euro area markets account only for about $8 \%$ of US asset price changes."

In addition, the U.S. dollar is the most common currency for international reserves to maintain the American interest rate low because of its liquidity (Conerly, 2013). Central banks are one of the major players in foreign exchange markets and when they intervene the U.S. dollar used as an intervention currency to stabilize the money supply and demand (Krugman, 1984).

However, from 2005 to 2015 that US dollar has faced with many challenges because of heated international events such as the global crisis in 2008, the debt crisis of the European Zone in 2010s, the global oil crisis, the wars in Ukraine, Libya, and the problems in the ASEAN zone and especially the strong emerging of Asian and Latin American economies and currencies in China, India, Mexico and Brazil. Within a decade, the U.S. dollar could be replaced as the world's reserve currency (Halligan, 2014). When the European Central Bank starts operating in 1999 and the single currency is issued in 2002, important shifts were expected in the reserve portfolios of central banks. It was believed that the advent of Euro would create an integrated monetary and financial zone larger than the United States (Hartmann, 1996; Bergsten, 1997; Schinasi, \& Prati, 1997; Greenspan, 2001; Gaspar, 2004; Papaioannou, Portes \& Siourounis, 2006; Chinn \& Frankel, 2007; Cohen, 2012). Moreover, it was expected that it would quickly come to rival and even surpass the dollar as the leading 
reserves by the central banks (Eichengreen, 1998).

After the depreciation of Euro to deal with the debt and banking crisis as contagious effects, other currencies were held the central banks as reserves such as Chinese yuan (Akram, Fatima, Mukhtar, \& Alam, 2011). Besides, Indian rupee, Brazilian real and Mexican peso have been becoming stronger and these three countries' GDP often dominate in the top 20 largest economies in the world (source: http://data.worldbank.org/).

Therefore, because of economic integration among countries, it is worth to explore affecting macro-economic factors on the foreign exchanges between USA and four emerging countries, China, India, Brazil and Mexico to understand why exchange rates fluctuate. The empirical findings reveal that the macro-economic factors statistically significantly predict and influence the exchange rates between USD/CNY, USD/INR, USD/BRL and USD/MNX. The results of this study could be utilized how the macroeconomic policies can be implemented in order to reduce the exchange rates movements.

The rest of the study is organized as follows. Section 2 examines literature review, Section 3 presents the methodology, Section 4 discusses the findings, and Section 6 concludes the study.

\section{Literature Review}

\subsection{Chinese Yuan}

Since the initiation of economic reforms, trade liberalization and lifting trade restrictions on the international trade a couple decades ago, China has been one of the world's fastest-growing economies and has emerged as a major economic and trade player (Morrison, 2009). The exchange rate system reform in July 2005 was considered as a historical regime switching in China (Ogawa \& Sakane, 2006). It ended the decade-long fixed nominal exchange rate of the renminbi vis-à-vis the US dollar (Goldstein \& Lardy, 2009). Chinese yuan has been allowed floating in a narrow margin around a fixed base rate determined with reference to a basket of world currencies. It is the result of exchange rate policy that promoted the rebalancing, which made China's goods and services become significantly more competitive in global markets (Goldstein, \& Lardy, 2009).

According to the IMF's (International Monetary Fund) national economic output in real terms of goods and services, China ranked 1st with $\$ 17.6$ trillion, slightly higher than USA with $\$ 17.4$ trillion. Rising US indebtedness combined with China's rising economic and financial skills have led some analysts to forecast the Chinese yuan would become the third reserve currencies after dollar and euro (Jaeger, Lanzeni, \& Mayer, 2010).

Based on the linear model of Chen, Peng, \& Shu (2009), the renminbi's share in the total world reserves is $10 \%$. This would provide benefits not only for China and also for the other countries. Chinese yuan will be an alternative for countries seeking to accumulate foreign currency reserves other than in dollar and euro (Eichengreen, 2011). Besides, the emergence of Asia, in particular Chinese economy, has been one of the most important features reshaping the world economy and providing an important source of global production and 
demand (Lee, 2014). Trade and foreign investment flows have been major factors in China's booming economy (Morrison, 2009). According to the United States Census Bureau, China ranked 2nd in trading with USA for a longtime (http://www.census.gov/). Moreover, Alicia and Koivu (2009) showed empirically that China's trade balance is sensitive to the fluctuations in the real effective exchange rate. As a result, examining macro-economic factors having an impact on foreign exchange rate between USA and China is important to reduce exchange rate movements.

\subsection{Indian Rupee}

Besides China, India is also considered as one of the largest and fastest growing economies in the world, which have been relatively less affected by the 2007-2008 global financial crises. Ranjan \& Prakash (2010) claimed that "against the backdrop of volatile capital flows, cautious movement towards internationalizing the rupee is in order as the size of the country in terms of GDP, volume of trade as also the turnover in the foreign exchange market when compared with global dimensions is small." Before 2005, Indian rupee is effectively pegged to the U.S. dollar (Patnaik, 2004). After 2005, India has a managed float foreign exchange policy with effective interventions of the Central Bank, Reserve Bank of India (RBI) (Goyal \& Arora, 2010; Lin, 2011).

During 2007 financial crisis, the Indian exchange rate channel was underutilized to reduce inflation (Goyal, 2012). However, Indian rupee has depreciated sharply against the dollar since July 2011 because of the recent fall in current account balance, and reduction in capital inflows (Rangarajan \& Mishra, 2013).

Another study conducted by Mirchandani (2012) using Pearson Correlation analyses to explore Indian exchange rate volatility from 1991-2010 showed that there are significant correlations between the volatility of rupee and interest rate, inflation rate, GDP and FDI. In addition, Kumar (2010) utilized autoregressive distributed lag (ARDL) modelling approach and found that among the identified variables chosen a priori based on theoretical arguments as determinants of real exchange rate, productivity differential, external openness, terms of trade and net foreign assets turn out to be statistically significant. Another research conducted by Shylajan, Sreejesh, \& Suresh (2011) utilized Johansen-Juselius procedure of cointegration analysis and Vector Error Correction Model (VECM) revealed that there are significant relationships between the rupee-dollar exchange rate and money supply, index of industrial production (IIP) and interest rate. Therefore, capturing macro-economic factors affecting to rupee-dollar exchange rate is crucial to support the long-term trade viability and both sides, the U.S. and India will benefit (Joshi, Mohan, Sood, Rajagopalam, Lohman, \& Scissors, 2013).

\subsection{Brazilian Real}

According to Forbes, Brazil's economy is the largest in Latin America and the second largest in the western hemisphere (Blankfeld, 2010). Brazil is also another member of BRICS, which makes up 40 percent of the world's population, 25 percent of the world's landmass, and about 20 percent of global GDP and control some 43 percent of global foreign exchange reserves 
(Van Agtmael, 2012).

Since 1999, Brazil has a floating exchange rate regime (Campa, Chang, \& Refalo, 2002; Tabak, 2006). Although the float is often described as free, but given the extent of recent reserve accumulation it would not qualify as a free float as understood by most economists (Williamson, 2010). Particular emphasis was placed on the specific microstructure of the Brazilian financial and currency markets, the existing inflation targeting regime with an officially floating exchange rate, and the operations of the BCB (Brazilian Central Bank) as ultimate provider of liquidity (Kaltenbrunner, 2011).

During the 2007 financial crisis, the cutoff of dollar funding lines to Brazilian corporations and banks in September and October 2008, led the BCB to introduce an array of foreign exchange liquidity easing measures in response to stresses in different markets (Stone, Walker, $\&$ Yasui, 2009). Consequently, early in 2009, Brazil did get the initial impact of the international financial crisis absorbed and the Brazilian economy, as a result, increased $7.5 \%$ in 2010 (Moreira, Prates, \& Ferrari-Filho, 2011). Specifically, Brazil focuses more actively on state promotion of domestic industries and economic actors within the international trade system (Santos, 2012).

However, the Brazilian currency, the real, experienced one of the world's largest exchange rate depreciations during the recent international financial crisis. This depreciation resulted from Brazil's rising international financialization (Kaltenbrunner, 2010). Understanding exchange rates trends between USA and Brazil appears to be vital for international trade. Nassif, Feijó, \& Araújo (2011) showed that the evolution of the Brazilian real exchange rate from 1999 to 2010 has been characterized by highly volatile and overvalued. According to Moura, Lima, \& Mendonça (2008), the exchange rate in Brazil is linked with current and future economic fundamentals and does not follow a random walk. Felisoni, Eunni, \& Manoel (2010), two-stage least squares (TSLS) regression was employed to show that exchange rates of Brazil did emerge significant to explain FDI inflows into Brazil during 2000-2007. Another study of Bahmani-Oskooee, Harvey \& Hegerty (2013) examined bilateral export and import flows between the United States and Brazil from 1971 to 2010 by using cointegration analysis to explore that exchange-rate volatility supported international commodity trade in long-run.

\subsection{Mexico Peso}

Mexico is the U.S. third-largest trading partner. Mexico ranks third as a source of U.S. imports, after China and Canada, and second, after Canada, as an export market for U.S. goods and services. The U.S. is the largest source of foreign direct investment (FDI) in Mexico (Villareal, 2015). A full 40\% of the content in U.S. imports from Mexico is actually produced in the United States. This means that forty cents of every dollar spent on imports from Mexico comes back to the U.S. (Wilson, 2011). Mexico has taken advantage of its relatively inexpensive labor to attract U.S. manufacturing firms and expand its exports with more than $70 \%$ of Mexico's exports go to the U.S. and the U.S. is Mexico's main trading partner for agricultural products (Bahmani-Oskooee \& Hegerty, 2009). Morevoer, Mexico pursues a policy of trade liberalization with the support of joining WTO (World Trade 
Organization) as a strategy for economic growth in itself (Santos, 2012).

During the 2007 financial crisis, Mexico had faced two considerable shocks not only the global economic recession, particularly due the U.S. led to a drop in Mexico's exports and a deterioration in its terms of trade but also the climate of extreme risk aversion among international investors and the global deleveraging process significantly constrained access to international financial markets (Sidaoui, Ramos-Francia, \& Cuadra, 2010). The real exchange rate of Mexico changed in response to a set of economic fundamentals has several policy implications in terms of the link between the exchange rate, and the capital flows, managing of the capital transactions (López Villavicencio \& Raymond Bara, 2008).

Kutty (2010) showed that stock prices lead exchange rates changes in the short run, and there is no long run relationship between them from 1989 to 2006. Loría, Sánchez, \& Salgado (2010) by using a cointegrated SVAR model proved that there was robust short and long-run relationships between the Mexican monetary aggregates and the exchange rate, which ultimately responds to what Bilson's variant of MAER predicts. Another research by Ibarra (2011) showed that not only portfolio investment but also FDI can strongly appreciate the recipient Mexico's currency from 1988 to 2008.

Therefore, this paper examines macro-economic factors affecting the exchange rates between the U.S. and four big emerging economies, China, India, Brazil and Mexico, which are the major international trading partners with the U.S. and have significant influences on the development of U.S. economy. Understanding the trends of foreign exchanges could stimulate not only the international trade, but also promote the potential opportunities of international investing in the future.

\section{Methodology}

\subsection{General Model}

This paper uses the following regression equation to test the impact of macro-economic factors on the exchange rates:

$$
\begin{gathered}
E X C H=\alpha+\beta I I N F+\beta 2 S I N+\beta 3 L I N+\beta 4 T R B A L A N C E+\beta 5 T R I M+\beta 6 T R E X+\beta 7 P U B D \\
+\beta \text { IINTRE }+\beta \text { TFDITRANS }+\beta 10 F D I I N C O M E+\beta 11 G D P+\varepsilon
\end{gathered}
$$

Where, EXCH is the foreign exchange of USD, Chinese yuan, Brazilian real, Indian rupee and Mexican pesos from 2005 to 2014 quarterly, $\alpha$ is the constant, $\beta 1$ to $\beta 11$ are the parameters to be estimated, INF is the inflation rate, SIN and LIN is the short-term and long-term interest rate respectively, TRBALANCE is the trade balance, TRIM is the import, TREX is the export, PUBD is the public debt rate to GDP, INTRE is international reserves, FDITRANS is the foreign direct investment for financial transaction, FDIINCOME is the foreign direct investment for Income, GDP is the growth rate, $\varepsilon$ is the random error term.

\subsection{Data}

The sample period for this paper on the impact of macro-economic factors on the exchange rates extends from January 2005 to December 2014 based on quarterly data. Following the 
previous studies, this study uses following macro-economic factors: inflation, interest rate, trade balance, public debt, international reserves, foreign direct investment, divided in two components-financial and income and GDP to examine the foreign exchange rate movements between USA and four big emerging countries, India, Mexico, Brazil and China. The data on the macro-economic are obtained from IMF, Worldbank, and the Unites States Census Bureau Websites.

\section{Empirical Findings}

\subsection{Descriptive Statistics}

Table 1 summarizes the descriptive statistics of the variables used in this research paper. There are totally 11 independent variables, which represent for 7 macro-economic factors, inflation, interest rate, trade balance, public debt, international reserves, and foreign direct investment (FDI) and gross domestic product (GDP). Besides, there are four dependent variables, USD/BRL, USD/MXN, USD/CNY and USD/INR, which are collected quarterly from January 2005 to December 2014.

Table 1. Descriptive of variables

\begin{tabular}{|c|c|c|c|c|c|c|c|}
\hline & $\mathbf{N}$ & Minimum & Maximum & Mean & Std. Deviation & Skewness & Kurtosis \\
\hline Financial China & 40 & -1007 & 1961 & 270.35 & 606.458 & 1.024 & 1.957 \\
\hline FinancialIndia & 40 & -323 & 616 & 188.08 & 230.689 & -.184 & .121 \\
\hline FinancialMexico & 40 & -2309 & 3636 & 340.45 & 1078.654 & .205 & 1.807 \\
\hline FinancialBrazil & 40 & -2761 & 2810 & 133.40 & 980.899 & .422 & 3.159 \\
\hline IncomeChina & 40 & -20 & 368 & 76.55 & 100.348 & 1.940 & 2.846 \\
\hline IncomeIndia & 39 & -30 & 151 & 78.51 & 47.962 & -.468 & -.594 \\
\hline IncomeMexico & 39 & -30 & 902 & 443.85 & 240.226 & .190 & -.661 \\
\hline IncomeBrazil & 35 & -58 & 155 & 17.43 & 41.980 & .960 & 2.082 \\
\hline GPD & 40 & -.032 & .069 & .03591 & .024258 & -1.400 & 2.055 \\
\hline Inflation & 40 & -.0163 & .0530 & .022955 & .0141429 & -.514 & .972 \\
\hline Long & 40 & .001133 & .054233 & .01864250 & .020724670 & .716 & -1.226 \\
\hline Short & 40 & .016433 & .050700 & .03332838 & .010146494 & .022 & -1.177 \\
\hline PublicDebt & 40 & .6007 & 1.0330 & .818400 & .1691114 & -.150 & -1.752 \\
\hline Reserve & 40 & 64473 & 153771 & 109835.88 & 35850.572 & -.154 & -1.929 \\
\hline USD/BRL & 40 & 1.5960 & 2.6615 & 2.025900 & .2737871 & .185 & -.894 \\
\hline USD/MXN & 40 & 10.3100 & 14.3600 & 12.171200 & 1.1426076 & -.139 & -1.366 \\
\hline $\mathrm{USD} / \mathrm{CNY}$ & 40 & 6.1180 & 8.2770 & 6.944563 & .7159548 & .614 & -1.034 \\
\hline USD/INR & 40 & 39.4915 & 62.1665 & 48.878088 & 6.6848968 & .774 & -.485 \\
\hline $\begin{array}{l}\text { TradeBalance } \\
\text { China }\end{array}$ & 40 & -96785.00 & -42005.00 & -68374.7750 & 13511.31861 & -.122 & -.743 \\
\hline ImportChina & 40 & 51008.30 & 127674.80 & 89599.1450 & 19826.27845 & .087 & -.880 \\
\hline ExportChina & 40 & 9003.80 & 39158.60 & 21224.4450 & 7584.65712 & .358 & -.623 \\
\hline TradeBalanceIndia & 40 & -6771.00 & -560.00 & -3295.9000 & 1535.83911 & -.391 & -.413 \\
\hline
\end{tabular}




\begin{tabular}{|l|l|l|l|l|l|l|l|}
\hline ImportIndia & 40 & 4336.70 & 11805.50 & 7620.7650 & 2389.91880 & .421 & -1.275 \\
\hline ExportIndia & 40 & 1796.30 & 6220.20 & 4325.0125 & 1358.99636 & -.508 & -1.008 \\
\hline TradeBalanceBrazil & 40 & -2544.00 & 4797.00 & 1315.0750 & 2229.76784 & -.333 & -1.086 \\
\hline ImportBrazil & 40 & 4724.40 & 9105.60 & 6823.8550 & 1134.10430 & .232 & -.725 \\
\hline ExportBrazil & 40 & 3382.50 & 12340.90 & 8138.8700 & 2694.49433 & -.256 & -1.345 \\
\hline TradeBalanceMexico & 40 & -21419.00 & -9706.00 & -15065.2750 & 2522.50346 & -.076 & -.069 \\
\hline ImportMexico & 40 & 38774.30 & 75445.70 & 57918.8525 & 11087.80061 & -.032 & -1.251 \\
\hline ExportMexico & 40 & 28141.60 & 61118.20 & 42853.6650 & 10898.94478 & .352 & -1.442 \\
\hline Valid N (listwise) & 34 & & & & & & \\
\hline
\end{tabular}

Notes. 11 predictors, which represent for 7 macro-economy factors: Inflation, Interest Rate, Trade Balance, Public Debt, International Reserves, Foreign Direct Investment (FDI) and Gross Domestic Product (GDP). 4 outcomes are USD/BRL, USD/MXN, USD/CNY and USD/INR. All of the variables are collected in quarterly from January 2005- December 2014.

\subsection{China}

The assumption of variables type was met because the outcome USD/CNY and 11 predictors are continuous. The independence of observation was also assumed. The assumption of Non-Zero variance was met because there are standard deviations of the predictors are unequal to 0. Based on the Figure 1, the assumption of Normally-distributed errors was met. Because the histogram followed the normal distribution and the Normal P-P plot followed a straight line.
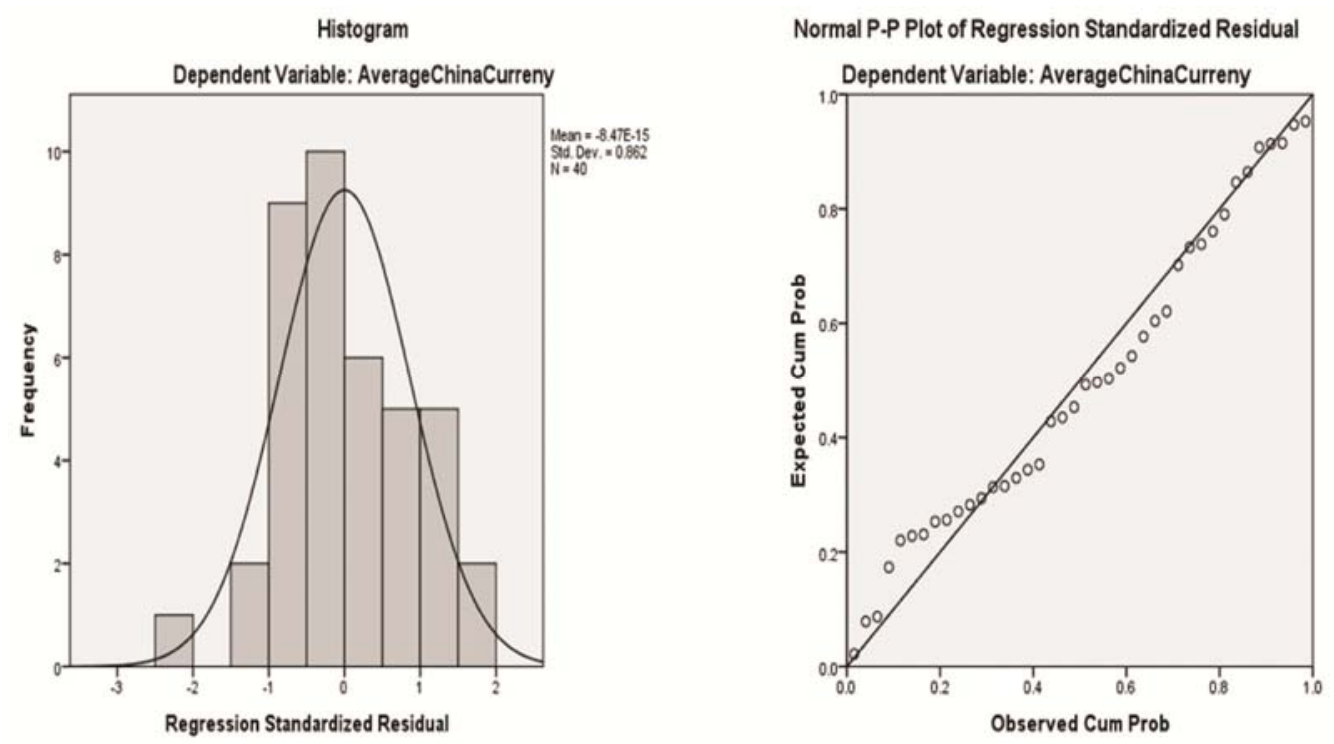

Figure 1. Histogram and normal P-P plot of the outcome USD/CNY

Table 2 shows that income FDI, long-term interest rate, short-term interest rate, public debt, national reserve, trade balance, export and import have a strong relationship with the USD/CNY exchange rate. However, public debt, national reserve, export and import have a negative correlation. 
Table 2. Pearson correlations among variables of USD/CNY

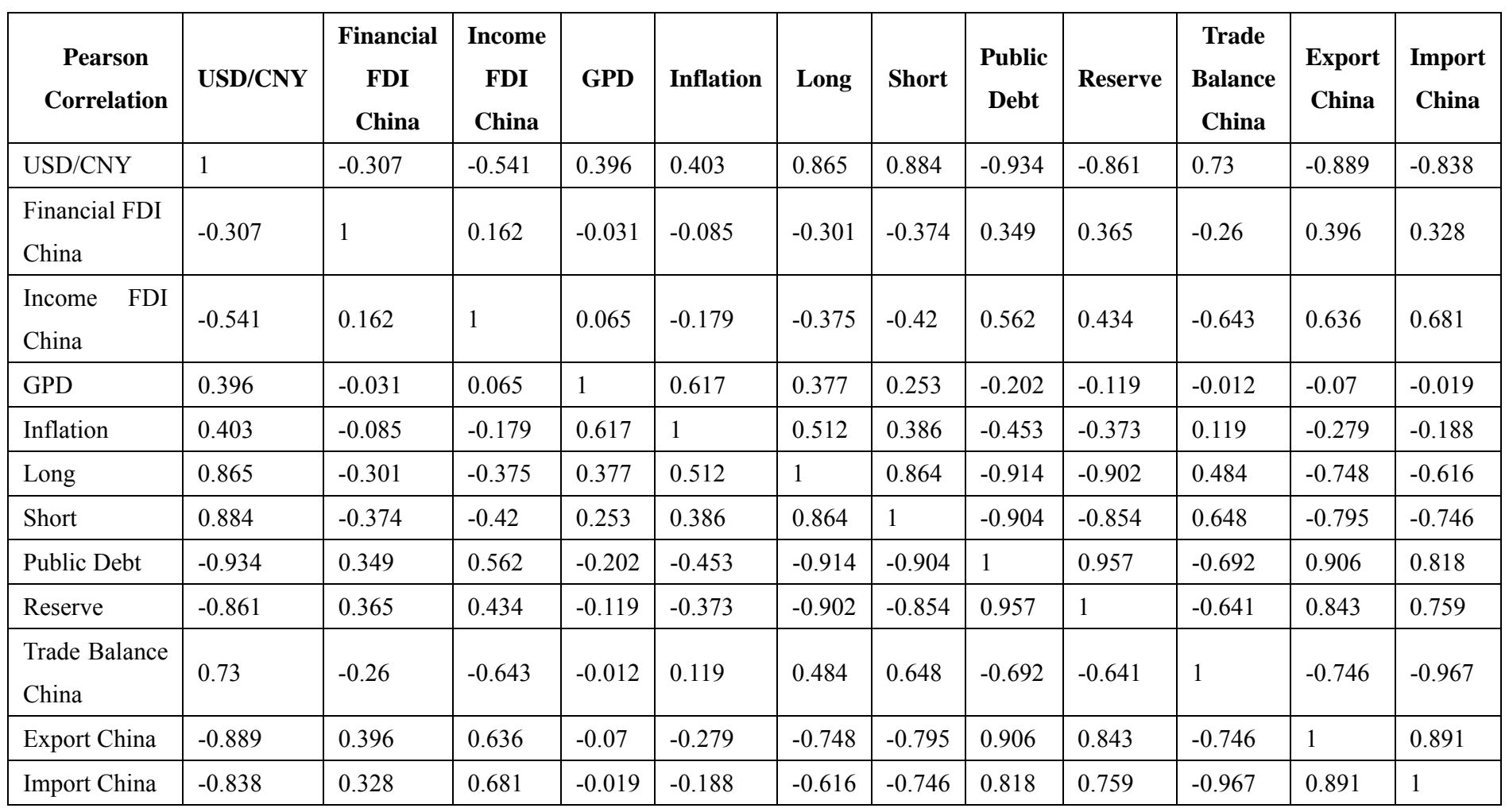

Notes. The foreign exchange USD/CNY has strong relationship with most of the macro-economy factors except for FDI (Financial), GDP and Inflation. USD/CNY also has a negative relationship with FDI, Public Debt, National Reserve, Export and Import.

\subsubsection{Macro-economic Determinants of USD/CNY}

The Multiple Regression excluded the import due to its too high VIF and Tolerance. In Table 3 , there is a statistical significance of the regression model because of $p$-value $=0(<0.01)$. It suggests that selected macro-economic factors have $98 \%$ explanatory power on USD/CNY exchange rate movements.

Table 3. Model summary and ANOVA of multiple regression of USD/CNY

\begin{tabular}{|c|c|c|c|c|c|c|c|c|c|}
\hline \multicolumn{4}{|c|}{ Model Summary } & \multicolumn{6}{|c|}{ ANOVA } \\
\hline $\mathbf{R}$ & R Square & $\begin{array}{c}\text { Adjusted R } \\
\text { Square }\end{array}$ & $\begin{array}{c}\text { Std. Error } \\
\text { of the } \\
\text { Estimate }\end{array}$ & & $\begin{array}{l}\text { Sum of } \\
\text { Squares }\end{array}$ & df & $\begin{array}{c}\text { Mean } \\
\text { Square }\end{array}$ & $\mathbf{F}$ & Sig. \\
\hline \multirow{3}{*}{$.990^{\mathrm{a}}$} & \multirow{3}{*}{0.98} & \multirow{3}{*}{0.973} & \multirow{3}{*}{0.1180331} & Regression & 19.587 & 10 & 1.959 & 140.592 & $.000^{\mathrm{b}}$ \\
\hline & & & & Residual & 0.404 & 29 & 0.014 & & \\
\hline & & & & Total & 19.991 & 39 & & & \\
\hline
\end{tabular}

Note. The multiple regression model with the method ENTER reflected $99 \%$ the correlation between the observed values of the fluctuations of USD/CNY and the values predicted by the model for 10 years in quarterly. Besides, the regression model of 10 variables also explained $98 \%$ (effect size) of the total variance of the predictors. 
Based on the results of Table 4 and Table 5, GDP, inflation rate, public debt, trade balance and export have statistically significantly impact on USD/CNY exchange rate ( $p$-value $<0.05$ ). The results indicated that $98 \%$ of the total variance of the exchange rate can be explained by the five predictors. GDP is statistically significantly positively related to USD/CNY exchange rate, $\beta=0.36, \mathrm{t}(38)=8.64, \mathrm{p}<0.001$. Inflation rate is statistically significantly negatively related to USD/CNY, $\beta=-0.20, \mathrm{t}(38)=-4.85, \mathrm{p}<0.001$. Public debt has a statistically significantly negatively impact on USD/CNY, $\beta=-0.65$, t $(38)=-3.28, \mathrm{p}<0.001$. Trade balance is statistically significantly positively related USD/CNY, $\beta=0.13, \mathrm{t}(38)=2.59, \mathrm{p}<$ 0.05 . However, export is statistically significantly negatively related to USD/CNY, $\beta=-0.26$, $\mathrm{t}(38)=-3.29, \mathrm{p}<0.05$. Maximum Cook's distance was 0.22 with a maximum standardized residual of 1.67 (from one subject) suggesting that there is a relatively high level of accuracy in the regression model.

Table 4. Coefficient results of the multiple regression of USD/CNY

\begin{tabular}{|c|c|c|c|c|c|c|c|c|}
\hline \multicolumn{9}{|c|}{ Coefficients } \\
\hline \multirow{2}{*}{ Coefficients } & \multicolumn{2}{|c|}{$\begin{array}{c}\text { Unstandardized } \\
\text { Coefficients }\end{array}$} & \multirow{2}{*}{$\begin{array}{c}\begin{array}{c}\text { Standardized } \\
\text { Coefficients }\end{array} \\
\text { Beta }\end{array}$} & \multirow{2}{*}{$\mathbf{t}$} & \multirow{2}{*}{ Sig. } & \multicolumn{3}{|c|}{ Correlations } \\
\hline & $\mathbf{B}$ & $\begin{array}{l}\text { Std. } \\
\text { Error }\end{array}$ & & & & Zero-order & Partial & Part \\
\hline (Constant) & 9.653 & 0.588 & & 16.41 & 0 & & & \\
\hline Financial FDI China & $6.04 \mathrm{E}-05$ & 0 & 0.051 & 1.703 & 0.099 & -0.307 & 0.302 & 0.045 \\
\hline Income FDI China & $2.88 \mathrm{E}-05$ & 0 & 0.004 & 0.091 & 0.928 & -0.541 & 0.017 & 0.002 \\
\hline GPD & 10.677 & 1.235 & 0.362 & 8.645 & 0 & 0.396 & 0.849 & 0.228 \\
\hline Inflation & -10.024 & 2.067 & -0.198 & -4.85 & 0 & 0.403 & -0.669 & -0.128 \\
\hline Long & -0.193 & 3.416 & -0.006 & -0.057 & 0.955 & 0.865 & -0.01 & -0.001 \\
\hline Short & 5.861 & 5.186 & 0.083 & 1.13 & 0.268 & 0.884 & 0.205 & 0.03 \\
\hline Public Debt & -2.761 & 0.841 & -0.652 & -3.283 & 0.003 & -0.934 & -0.52 & -0.087 \\
\hline Reserve & $1.62 \mathrm{E}-06$ & 0 & 0.081 & 0.628 & 0.535 & -0.861 & 0.116 & 0.017 \\
\hline Export China & $-2.47 \mathrm{E}-05$ & 0 & -0.261 & -3.289 & 0.003 & -0.889 & -0.521 & -0.087 \\
\hline Trade Balance China & $6.82 \mathrm{E}-06$ & 0 & 0.129 & 2.587 & 0.015 & 0.73 & 0.433 & 0.068 \\
\hline
\end{tabular}

Note. A standard multiple regression was conducted to examine the relationship between predictors of macro-economy factors with the outcome USD/CNY in quarterly from 2005 to 2014. The model indicated that GDP, Inflation rate, Public Debt, Trade Balance and Export significantly predict the outcome: exchange rate USD/CNY (p-value $<0.05$ ). 
Table 5. Residual result of the multiple regression of USD/CNY

\begin{tabular}{|l|l|l|l|l|l|}
\hline \multicolumn{7}{|c|}{ Residuals Statistics } \\
\hline & Minimum & Maximum & Mean & Std. Deviation & N \\
\hline Predicted Value & 5.941669 & 8.279169 & 6.944563 & .7086831 & 40 \\
\hline Std. Predicted Value & -1.415 & 1.883 & .000 & 1.000 & 40 \\
\hline Standard Error of Predicted Value & .045 & .094 & .060 & .013 & 40 \\
\hline Adjusted Predicted Value & 5.834743 & 8.280347 & 6.945422 & .7114616 & 40 \\
\hline Residual & -.2381982 & .1973303 & .0000000 & .1017817 & 40 \\
\hline Std. Residual & -2.018 & 1.672 & .000 & .862 & 40 \\
\hline Stud. Residual & -2.399 & 2.076 & -.004 & 1.006 & 40 \\
\hline Deleted Residual & -.3366477 & .3042566 & -.0008596 & .1402226 & 40 \\
\hline Stud. Deleted Residual & -2.633 & 2.211 & -.002 & 1.039 & 40 \\
\hline Mahal. Distance & 4.626 & 23.627 & 9.750 & 4.950 & 40 \\
\hline Cook's Distance & .000 & .216 & .035 & .051 & 40 \\
\hline Centered Leverage Value & .119 & .606 & .250 & .127 & 40 \\
\hline
\end{tabular}

Note. Maximum Cook's distance was 0.22 with a maximum standardized residual of 1.67 (from one subject) suggesting a relatively high level of accuracy of the regression model. The contributions of each predictor could be arranged as Public Debt $>$ GDP $>$ Export $>$ Inflation $>$ Balance.

\subsubsection{The Effects of the Import Predictor on USD/CNY Exchange Rate}

To explore the influences of the import predictor, the paper implemented the multiple regression with the method STEPWISE. The results of the multiple regressions in Table 6 indicate that four models could significantly explain the variances in USD/CNY exchange rate. These models also have $p$-values of ANOVA in Table 7 equal to 0 (p-value $<0.001$ ). The STEPWISE multiple regression results in Table 8 also reveal that public debt, GDP, inflation and import have a significant impact statistically. The import is significant (p-value $<0.001$ ) for the third and fourth model indicating that it is also a determinant of USD/CNY exchange rate.

Table 6. Model summary of STEPWISE multiple regression of USD/CNY

\begin{tabular}{|c|c|c|c|c|c|c|c|c|c|}
\hline \multicolumn{10}{|c|}{ Model Summary } \\
\hline \multirow[b]{2}{*}{ Model } & \multirow[b]{2}{*}{$\mathbf{R}$} & \multirow[b]{2}{*}{ R Square } & \multirow[b]{2}{*}{$\begin{array}{l}\text { Adjusted R } \\
\text { Square }\end{array}$} & \multirow[b]{2}{*}{$\begin{array}{l}\text { Std. Error of the } \\
\text { Estimate }\end{array}$} & \multicolumn{5}{|c|}{ Change Statistics } \\
\hline & & & & & $\begin{array}{c}\text { R Square } \\
\text { Change }\end{array}$ & $\begin{array}{c}\text { F } \\
\text { Change }\end{array}$ & df1 & df2 & $\begin{array}{c}\text { Sig. F } \\
\text { Change }\end{array}$ \\
\hline 1 & $.934^{\mathrm{a}}$ & .872 & .868 & .2597049 & .872 & 258.398 & 1 & 38 & .000 \\
\hline 2 & $.957^{\mathrm{b}}$ & .917 & .912 & .2122543 & .045 & 19.889 & 1 & 37 & .000 \\
\hline 3 & $.976^{\mathrm{c}}$ & .953 & .949 & .1617042 & .036 & 27.749 & 1 & 36 & .000 \\
\hline 4 & $.987^{\mathrm{d}}$ & .974 & .970 & .1229963 & .021 & 27.224 & 1 & 35 & .000 \\
\hline
\end{tabular}

Note. The result of multiple regression with the method STEPWISE indicated 4 models, which could significantly predict the outcome USD/CNY. These four models could reflect up to more than $90 \%$ the correlation between the observed values of the outcome USD/CNY, and the values predicted by the model. Moreover, the R Squares (effect size) are more than $87.2 \%$ of the total variance of the predictors can be explained by the regression model. 
Table 7. ANOVA result of STEPWISE multiple regression of USD/CNY

\begin{tabular}{|c|c|c|c|c|c|c|}
\hline \multicolumn{7}{|c|}{ ANOVA } \\
\hline & Model & Sum of Squares & df & Mean Square & $\mathbf{F}$ & Sig. \\
\hline \multirow{3}{*}{1} & Regression & 17.428 & 1 & 17.428 & 258.398 & $.000^{\mathrm{b}}$ \\
\hline & Residual & 2.563 & 38 & .067 & & \\
\hline & Total & 19.991 & 39 & & & \\
\hline \multirow{3}{*}{2} & Regression & 18.324 & 2 & 9.162 & 203.367 & $.000^{\mathrm{c}}$ \\
\hline & Residual & 1.667 & 37 & .045 & & \\
\hline & Total & 19.991 & 39 & & & \\
\hline \multirow{3}{*}{3} & Regression & 19.050 & 3 & 6.350 & 242.843 & $.000^{\mathrm{d}}$ \\
\hline & Residual & .941 & 36 & .026 & & \\
\hline & Total & 19.991 & 39 & & & \\
\hline \multirow{3}{*}{4} & Regression & 19.462 & 4 & 4.865 & 321.613 & $.000^{\mathrm{e}}$ \\
\hline & Residual & .529 & 35 & .015 & & \\
\hline & Total & 19.991 & 39 & & & \\
\hline
\end{tabular}

Note. These model also have p-values of ANOVA equal to 0 (p-value $<0.001)$.

Table 8. Coefficient result of STEPWISE multiple regression of USD/CNY

\begin{tabular}{|c|c|c|c|c|c|c|c|c|c|}
\hline \multicolumn{10}{|c|}{ Coefficients } \\
\hline & \multirow{2}{*}{ Model } & \multicolumn{2}{|c|}{$\begin{array}{c}\text { Unstandardized } \\
\text { Coefficients }\end{array}$} & \multirow{2}{*}{$\begin{array}{c}\text { Standardized } \\
\text { Coefficients }\end{array}$} & \multirow{2}{*}{ t } & \multirow{2}{*}{ Sig. } & \multicolumn{3}{|c|}{ Correlations } \\
\hline & & B & Std. Error & & & & Zero-order & Partial & Part \\
\hline \multirow{2}{*}{1} & (Constant) & 10.180 & .205 & & 49.560 & .000 & & & \\
\hline & PublicDebt & -3.953 & .246 & -.934 & -16.075 & .000 & -.934 & -.934 & -.934 \\
\hline \multirow{3}{*}{2} & (Constant) & 9.799 & .188 & & 52.034 & .000 & & & \\
\hline & PublicDebt & -3.768 & .205 & -.890 & -18.360 & .000 & -.934 & -.949 & -.872 \\
\hline & GPD & 6.380 & 1.431 & .216 & 4.460 & .000 & .396 & .591 & .212 \\
\hline \multirow{4}{*}{3} & (Constant) & 9.844 & .144 & & 68.494 & .000 & & & \\
\hline & PublicDebt & -2.535 & .281 & -.599 & -9.007 & .000 & -.934 & -.832 & -.326 \\
\hline & GPD & 7.930 & 1.129 & .269 & 7.024 & .000 & .396 & .760 & .254 \\
\hline & ImportChina & $-1.239 \mathrm{E}-05$ & .000 & -.343 & -5.268 & .000 & -.838 & -.660 & -.191 \\
\hline \multirow{5}{*}{4} & (Constant) & 10.204 & .129 & & 78.947 & .000 & & & \\
\hline & PublicDebt & -3.086 & .239 & -.729 & -12.928 & .000 & -.934 & -.909 & -.356 \\
\hline & GPD & 10.993 & 1.040 & .372 & 10.568 & .000 & .396 & .873 & .291 \\
\hline & ImportChina & $-9.886 \mathrm{E}-06$ & .000 & -.274 & -5.339 & .000 & -.838 & -.670 & -.147 \\
\hline & Inflation & -10.568 & 2.025 & -.209 & -5.218 & .000 & .403 & -.661 & -.144 \\
\hline
\end{tabular}

Note. The STEPWISE multiple regression also highlighted the significant predictions and influences of Public Debt, GDP growth rate, Inflation and Import. Especially, the import predictor is significant (p-value $<0.001$ ) for the third and fourth model with the relative contribution. It means that the import predictor is also a determinant to the fluctuations of the foreign exchange USD/CNY. 


\subsection{India}

The assumption of variables type was met because the outcome USD/INR and 11 predictors are continuous. The independence of observation was also assumed. The assumption of Non-Zero variance was met because there are standard deviations of the predictors are unequal to 0. Based on the Figure 2, the assumption of Normally-distributed errors was met. Because the histogram followed the normal distribution and the Normal P-P plot followed a straight line.
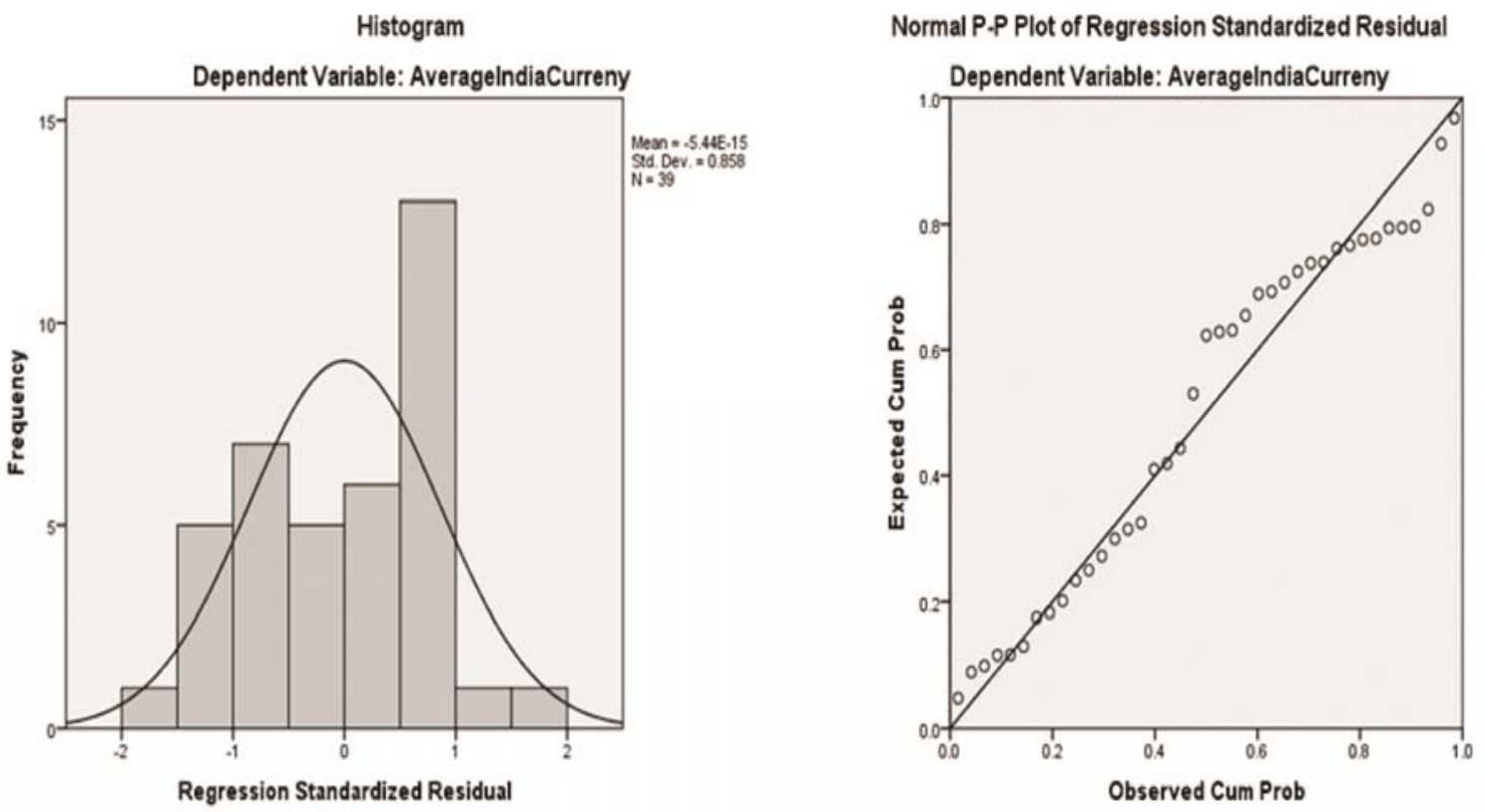

Figure 2. Histogram and normal P-P plot of the outcome USD/INR

Table 9 shows that long-term interest rate, short-term interest rate and trade balance have negative relationships with USD/INR exchange rate.

Table 9. Pearson correlations among variables of USD/INR

\begin{tabular}{|c|c|c|c|c|c|c|c|c|c|c|c|c|}
\hline \multicolumn{13}{|c|}{ Correlations } \\
\hline $\begin{array}{c}\text { Pearson } \\
\text { Correlations }\end{array}$ & $\begin{array}{l}\text { USD/ } \\
\text { INR }\end{array}$ & $\begin{array}{l}\text { Financial } \\
\text { FDI India }\end{array}$ & $\begin{array}{c}\text { Income } \\
\text { FDI India }\end{array}$ & GPD & Inflation & Long & Short & $\begin{array}{c}\text { Public } \\
\text { Debt }\end{array}$ & Reserve & $\begin{array}{c}\text { Trade } \\
\text { Balance } \\
\text { India }\end{array}$ & $\begin{array}{l}\text { Import } \\
\text { India }\end{array}$ & $\begin{array}{c}\text { Export } \\
\text { India }\end{array}$ \\
\hline USD/INR & 1.000 & -.240 & .537 & -.103 & -.459 & -.644 & -.708 & .796 & .670 & -.736 & .778 & .537 \\
\hline $\begin{array}{l}\text { Financial } \\
\text { FDI India }\end{array}$ & -.240 & 1.000 & -.029 & -.017 & .126 & .010 & .043 & -.063 & -.100 & .099 & -.077 & -.023 \\
\hline $\begin{array}{l}\text { Income FDI } \\
\text { India }\end{array}$ & .537 & -.029 & 1.000 & .006 & -.134 & -.740 & -.759 & .744 & .758 & -.521 & .673 & .600 \\
\hline GPD & -.103 & -.017 & .006 & 1.000 & .605 & .353 & .224 & -.170 & -.082 & -.379 & .104 & -.258 \\
\hline
\end{tabular}




\begin{tabular}{|l|c|c|c|c|c|c|c|c|c|c|c|c|}
\hline Inflation & -.459 & .126 & -.134 & .605 & 1.000 & .496 & .366 & -.435 & -.352 & .004 & -.130 & -.229 \\
\hline Long & -.644 & .010 & -.740 & .353 & .496 & 1.000 & .859 & -.911 & -.899 & .410 & -.662 & -.712 \\
\hline Short & -.708 & .043 & -.759 & .224 & .366 & .859 & 1.000 & -.900 & -.849 & .560 & -.791 & -.768 \\
\hline Public Debt & .796 & -.063 & .744 & -.170 & -.435 & -.911 & -.900 & 1.000 & .955 & -.648 & .869 & .804 \\
\hline Reserve & .670 & -.100 & .758 & -.082 & -.352 & -.899 & -.849 & .955 & 1.000 & -.598 & .816 & .769 \\
\hline $\begin{array}{l}\text { Trade } \\
\text { Balance }\end{array}$ & -.736 & .099 & -.521 & -.379 & .004 & .410 & .560 & INR & -.598 & 1.000 & -.857 & -.369 \\
India & & & & & & & & & & & \\
\hline $\begin{array}{l}\text { Import } \\
\text { India }\end{array}$ & .778 & -.077 & .673 & .104 & -.130 & -.662 & -.791 & .869 & .816 & -.857 & 1.000 & .796 \\
\hline $\begin{array}{l}\text { Export } \\
\text { India }\end{array}$ & .537 & -.023 & .600 & -.258 & -.229 & -.712 & -.768 & .804 & .769 & -.369 & .796 \\
\hline
\end{tabular}

Note. The foreign exchange USD/INR has strong relationship with the macro-economic factors: Interest rate (Long and Short), Public Debt, National Reserve, Trade Balance and Import. USD/INR also has a negative relationship with FDI (Financial, GDP, Inflation, Interest Rate and Trade Balance.

\subsubsection{Macro-economic Determinants to the USD/INR}

Import is excluded from the multiple regression equation due to its too high VIF and Tolerance. As can be seen from Table 10, the regression model of 10 variables explains $86.2 \%$ (effect size) of the total variance in USD/INR exchange rate significantly. This indicates that selected macro-economic factors have $86.2 \%$ of explanatory power on USD/INR exchange rate.

Table 10. Model summary and ANOVA of multiple regression of USD/INR

\begin{tabular}{|c|c|c|c|c|c|c|c|c|c|}
\hline \multicolumn{4}{|c|}{ Model Summary } & \multicolumn{6}{|c|}{ ANOVA } \\
\hline $\mathbf{R}$ & $\begin{array}{c}\mathbf{R} \\
\text { Square }\end{array}$ & $\begin{array}{c}\text { Adjusted R } \\
\text { Square }\end{array}$ & $\begin{array}{c}\text { Std. Error } \\
\text { of the } \\
\text { Estimate }\end{array}$ & Model & $\begin{array}{c}\text { Sum of } \\
\text { Squares }\end{array}$ & df & $\begin{array}{c}\text { Mean } \\
\text { Square }\end{array}$ & $\mathbf{F}$ & Sig. \\
\hline \multirow{3}{*}{$.929^{\mathrm{a}}$} & \multirow{3}{*}{.862} & \multirow{3}{*}{.813} & \multirow{3}{*}{2.9173454} & Regression & 1491.492 & 10 & 149.149 & 17.524 & $.000^{\mathrm{b}}$ \\
\hline & & & & Residual & 238.305 & 28 & 8.511 & & \\
\hline & & & & Total & 1729.798 & 38 & & & \\
\hline
\end{tabular}

Note. The multiple regression model with the method ENTER reflected $92.9 \%$ the correlation between the observed values of the fluctuations of USD/INR and the values predicted by the model for 10 years in quarterly. Besides, the regression model of 10 variables also explained $86.2 \%$ (effect size) of the total variance of the predictors.

According to results from Table 11 and 12, financial FDI, public debt, national reserve, trade balance have a significant impact on USD/INR exchange rate ( $p$-value $<0.05$ ). Financial FDI has statistically significantly negatively related to USD/INR exchange rate, $\beta=-0.19, t(37)=$ $-2.53, p<0.05$. Trade Balance has statistically significantly negatively effect on the exchange 
rate of USD/INR, $\beta=-0.44, t(37)=-2.81, p<0.05$. Public debt is statistically significantly positively related to USD/INR exchange rate, $\beta=1.26, t(37)=2.76, p<0.05$. National reserve has a statistically significantly negatively effect on USD/INR exchange rate, $\beta=-0.91$, $t(37)=-3.03, p<0.05$. Maximum Cook's distance from Table 12 is 0.23 with a maximum standardized residual of 1.85 (from one subject) suggesting that there is a relatively high level of accuracy in the regression model.

Table 11. Coefficient result of the multiple regression of USD/INR

\begin{tabular}{|c|c|c|c|c|c|c|c|c|}
\hline \multicolumn{9}{|c|}{ Coefficients } \\
\hline \multirow{2}{*}{ Model } & \multicolumn{2}{|c|}{ Unstandardized Coefficients } & \multirow{2}{*}{$\begin{array}{c}\begin{array}{c}\text { Standardized } \\
\text { Coefficients }\end{array} \\
\text { Beta } \\
\end{array}$} & \multirow{2}{*}{$\mathbf{t}$} & \multirow{2}{*}{ Sig. } & \multicolumn{3}{|c|}{ Correlations } \\
\hline & $\mathbf{B}$ & Std. Error & & & & Zero-order & Partial & Part \\
\hline (Constant) & 23.335 & 12.737 & & 1.832 & .078 & & & \\
\hline FinancialIndia & -.005 & .002 & -.187 & -2.526 & .017 & -.240 & -.431 & -.177 \\
\hline IncomeIndia & .003 & .018 & .018 & .146 & .885 & .537 & .028 & .010 \\
\hline GPD & -3.632 & 36.198 & -.013 & -.100 & .921 & -.103 & -.019 & -.007 \\
\hline Inflation & -84.818 & 56.340 & -.178 & -1.505 & .143 & -.459 & -.274 & -.106 \\
\hline Long & -21.880 & 89.109 & -.067 & -.246 & .808 & -.644 & -.046 & -.017 \\
\hline Short & 18.628 & 121.376 & .028 & .153 & .879 & -.708 & .029 & .011 \\
\hline PublicDebt & 50.509 & 18.321 & 1.257 & 2.757 & .010 & .796 & .462 & .193 \\
\hline Reserve & .001 & .001 & -.907 & -3.027 & .005 & .670 & -.497 & -.212 \\
\hline BalanceIndia & -.002 & .001 & -.436 & -2.815 & .009 & -.736 & -.470 & -.197 \\
\hline ExportIndia & .001 & .001 & -.021 & -.134 & .894 & .537 & -.025 & -.009 \\
\hline
\end{tabular}

Note. A standard multiple regression was conducted to examine the relationship between predictors of macro-economy factors with the outcome USD/INR in quarterly from 2005 to 2014. The model indicated that Financial FDI, Public Debt, National Reserve and Trade Balance significantly predict the outcome: exchange rate USD/INR (p-value $<0.05$ ).

Table 12. Residual result of the multiple regression of USD/INR

\begin{tabular}{|l|c|c|c|c|c|}
\hline \multicolumn{7}{|c|}{ Residuals Statistics } \\
\hline & Minimum & Maximum & Mean & $\begin{array}{c}\text { Std. } \\
\text { Deviation }\end{array}$ & N \\
\hline Predicted Value & 38.413094 & 61.938473 & 48.969474 & 6.2649657 & 39 \\
\hline Std. Predicted Value & -1.685 & 2.070 & .000 & 1.000 & 39 \\
\hline $\begin{array}{l}\text { Standard Error of Predicted } \\
\text { Value }\end{array}$ & 1.128 & 2.392 & 1.524 & .284 & 39 \\
\hline Adjusted Predicted Value & 36.072819 & 62.519463 & 48.784856 & 6.6140403 & 39 \\
\hline Residual & -4.8598824 & 5.3924074 & .0000000 & 2.5042350 & 39 \\
\hline Std. Residual & -1.666 & 1.848 & .000 & .858 & 39 \\
\hline Stud. Residual & -1.996 & 2.004 & .024 & 1.004 & 39 \\
\hline Deleted Residual & -6.9781394 & 6.3404737 & .1846182 & 3.4955071 & 39 \\
\hline Stud. Deleted Residual & -2.117 & 2.127 & .021 & 1.023 & 39 \\
\hline Mahal. Distance & 4.708 & 24.579 & 9.744 & 4.248 & 39 \\
\hline Cook's Distance & .000 & .234 & .038 & .047 & 39 \\
\hline Centered Leverage Value & .124 & .647 & .256 & .112 & 39 \\
\hline
\end{tabular}

Note. Maximum Cook's distance was 0.23 with a maximum standardized residual of 1.85 (from one subject) suggesting a relatively high level of accuracy of the regression model. 


\subsubsection{The Effects of the Import Predictor to the Outcome USD/INR}

To explore the influences of the import predictor, the paper implements the multiple regressions with the STEPWISE method. The results the multiple regression model in in Table 13 indicate five models could significantly affect USD/INR exchange rate. These five models could reflect up to more than $79.6 \%$ the correlation between the observed values of the outcome USD/INR exchange rate and the values predicted by the model. The R-Squares (effect size) are more than $63.4 \%$ of the total variance in USD/INR exchange rates can be explained by the macro-economic factors. These models also have p-values of ANOVA in Table 14 equal to 0 ( $\mathrm{p}$-value $<0.001$ ). The STEPWISE multiple regressions in Table 15 also show that public debt, national reserve, trade balance, financial FDI and inflation have a significant impact on USD/INR exchange rate.

Table 13. Model summary of STEPWISE multiple regression of USD/INR

\begin{tabular}{|c|c|c|c|c|}
\hline \multicolumn{5}{|c|}{ Model Summary } \\
\hline Model & R & R Square & Adjusted R Square & Std. Error of the Estimate \\
\hline $\mathbf{1}$ & $.796^{\mathrm{a}}$ & .634 & .624 & 4.1393117 \\
\hline $\mathbf{2}$ & $.853^{\mathrm{b}}$ & .727 & .712 & 3.6233566 \\
\hline $\mathbf{3}$ & $.891^{\mathrm{c}}$ & .795 & .777 & 3.1850043 \\
\hline $\mathbf{4}$ & $.916^{\mathrm{d}}$ & .839 & .821 & 2.8576753 \\
\hline $\mathbf{5}$ & $.928^{\mathrm{e}}$ & .861 & .840 & 2.6979151 \\
\hline
\end{tabular}

Note. The result of multiple regression with the method STEPWISE indicated 5 models, which could significantly predict the outcome USD/INR. These four models could reflect up to more than $79.6 \%$ the correlation between the observed values of the outcome USD/INR, and the values predicted by the model. Moreover, the R Squares (effect size) are more than $63.4 \%$ of the total variance of the predictors can be explained by the regression model.

Table 14. ANOVA result of STEPWISE multiple regression of USD/INR

\begin{tabular}{|c|c|c|c|c|c|c|}
\hline \multicolumn{7}{|c|}{ ANOVA } \\
\hline \multicolumn{2}{|r|}{ Model } & Sum of Squares & df & Mean Square & $\mathbf{F}$ & Sig. \\
\hline \multirow[t]{3}{*}{1} & Regression & 1095.843 & 1 & 1095.843 & 63.958 & $.000^{\mathrm{b}}$ \\
\hline & Residual & 633.954 & 37 & 17.134 & & \\
\hline & Total & 1729.798 & 38 & & & \\
\hline \multirow[t]{3}{*}{2} & Regression & 1257.164 & 2 & 628.582 & 47.878 & $.000^{\mathrm{c}}$ \\
\hline & Residual & 472.634 & 36 & 13.129 & & \\
\hline & Total & 1729.798 & 38 & & & \\
\hline \multirow[t]{3}{*}{3} & Regression & 1374.749 & 3 & 458.250 & 45.173 & $.000^{\mathrm{d}}$ \\
\hline & Residual & 355.049 & 35 & 10.144 & & \\
\hline & Total & 1729.798 & 38 & & & \\
\hline \multirow[t]{3}{*}{4} & Regression & 1452.143 & 4 & 363.036 & 44.455 & $.000^{\mathrm{e}}$ \\
\hline & Residual & 277.654 & 34 & 8.166 & & \\
\hline & Total & 1729.798 & 38 & & & \\
\hline \multirow[t]{3}{*}{5} & Regression & 1489.599 & 5 & 297.920 & 40.930 & $.000^{\mathrm{f}}$ \\
\hline & Residual & 240.199 & 33 & 7.279 & & \\
\hline & Total & 1729.798 & 38 & & & \\
\hline
\end{tabular}

Note. These model also have p-values of ANOVA equal to 0 ( $\mathrm{p}$-value $<0.001$ ). 
Table 15. Coefficient result of STEPWISE multiple regression of USD/INR

\begin{tabular}{|c|c|c|c|c|c|c|c|c|c|}
\hline \multicolumn{10}{|c|}{ Coefficients } \\
\hline & \multirow[t]{2}{*}{ Model } & \multicolumn{2}{|c|}{$\begin{array}{c}\text { Unstandardized } \\
\text { Coefficients }\end{array}$} & \multirow{2}{*}{$\begin{array}{c}\text { Standardized } \\
\text { Coefficients }\end{array}$} & \multirow[t]{2}{*}{$\mathbf{t}$} & \multirow[t]{2}{*}{ Sig. } & \multicolumn{3}{|c|}{ Correlations } \\
\hline & & B & Std. Error & & & & Zero-order & Partial & Part \\
\hline \multirow{2}{*}{1} & (Constant) & 22.621 & 3.361 & & 6.731 & .000 & & & \\
\hline & PublicDebt & 31.987 & 4.000 & .796 & 7.997 & .000 & .796 & .796 & .796 \\
\hline \multirow{3}{*}{2} & (Constant) & 11.688 & 4.287 & & 2.726 & .010 & & & \\
\hline & PublicDebt & 71.733 & 11.867 & 1.785 & 6.045 & .000 & .796 & .710 & .527 \\
\hline & Reserve & .000 & .000 & -1.035 & -3.505 & .001 & .670 & -.504 & -.305 \\
\hline \multirow{4}{*}{3} & (Constant) & 15.047 & 3.896 & & 3.863 & .000 & & & \\
\hline & PublicDebt & 59.492 & 11.033 & 1.480 & 5.392 & .000 & .796 & .674 & .413 \\
\hline & Reserve & .000 & .000 & -.950 & -3.642 & .001 & .670 & -.524 & -.279 \\
\hline & BalanceIndia & -.001 & .000 & -.344 & -3.405 & .002 & -.736 & -.499 & -.261 \\
\hline \multirow{5}{*}{4} & (Constant) & 15.333 & 3.497 & & 4.385 & .000 & & & \\
\hline & PublicDebt & 63.702 & 9.993 & 1.585 & 6.374 & .000 & .796 & .738 & .438 \\
\hline & Reserve & .000 & .000 & -1.056 & -4.466 & .000 & .670 & -.608 & -.307 \\
\hline & BalanceIndia & -.001 & .000 & -.318 & -3.498 & .001 & -.736 & -.514 & -.240 \\
\hline & FinancialIndia & -.006 & .002 & -.215 & -3.079 & .004 & -.240 & -.467 & -.212 \\
\hline \multirow{6}{*}{5} & (Constant) & 22.575 & 4.592 & & 4.916 & .000 & & & \\
\hline & PublicDebt & 50.804 & 11.016 & 1.264 & 4.612 & .000 & .796 & .626 & .299 \\
\hline & Reserve & .000 & .000 & -.875 & -3.688 & .001 & .670 & -.540 & -.239 \\
\hline & BalanceIndia & -.002 & .000 & -.420 & -4.335 & .000 & -.736 & -.602 & -.281 \\
\hline & FinancialIndia & -.005 & .002 & -.183 & -2.707 & .011 & -.240 & -.426 & -.176 \\
\hline & Inflation & -91.717 & 40.431 & -.192 & -2.268 & .030 & -.459 & -.367 & -.147 \\
\hline
\end{tabular}

Note. The STEPWISE multiple regression also highlighted the significant predictions and influences of Public Debt, National Reserve, Inflation, Trade Balance and Financial FDI. Especially, the import predictor is not significant, but inflation is significant for the fifth model with the relative contribution. It means that inflation is also a determinant to the fluctuations of the foreign exchange USD/INR.

\subsection{Brazil}

As can be seen from Figure 3, the assumption of variables type was met because the outcome USD/BRL and 11 predictors are continuous. The independence of observation was also assumed. The assumption of Non-Zero variance was met because there are standard deviations of the predictors are unequal to 0 . In addition, the assumption of Normally-distributed errors was met. Because the histogram followed the normal distribution and the Normal P-P plot followed a straight line. 

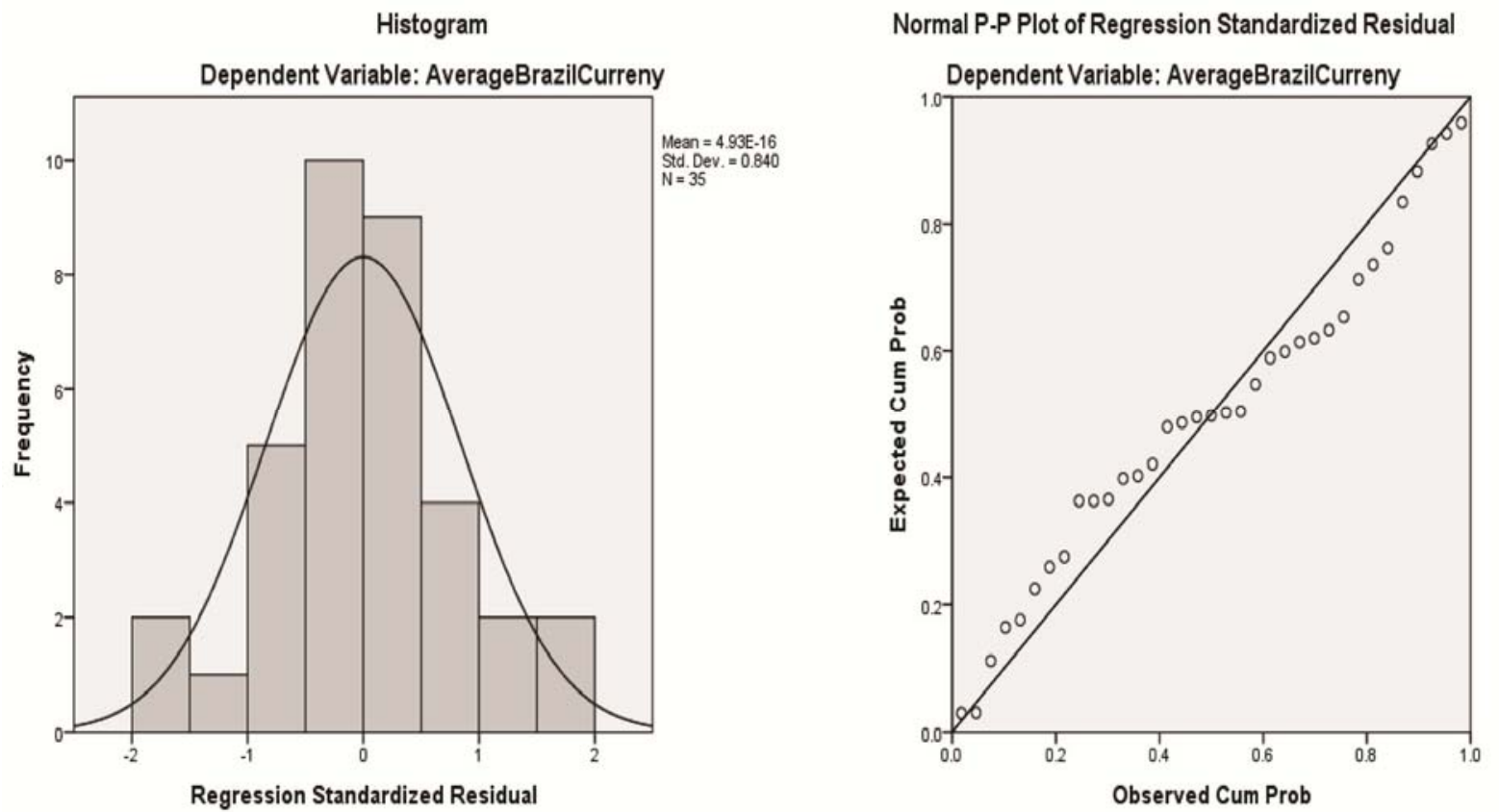

Figure 3. Histogram and normal P-P plot of the outcome USD/BRL

\subsubsection{Relationships among Variables}

Table 16 shows that macro-economic factors have low correlations with USD/BRL exchange rate. Most of them have negative relationship with the exchange rate except inflation, income FDI and interest rate.

Table 16. Pearson correlations among variables of USD/BRL

\begin{tabular}{|l|c|c|c|c|c|c|c|c|c|c|c|c|}
\hline \multicolumn{1}{|c|}{} & USD/BRL & $\begin{array}{c}\text { Financial } \\
\text { FDI } \\
\text { Brazil }\end{array}$ & $\begin{array}{c}\text { Income } \\
\text { FDI } \\
\text { Brazil }\end{array}$ & GPD & Inflation & Long & Short & $\begin{array}{c}\text { Public } \\
\text { Debt }\end{array}$ & Reserve & $\begin{array}{c}\text { Trade } \\
\text { Balance } \\
\text { Brazil }\end{array}$ & $\begin{array}{c}\text { Import } \\
\text { Brazil }\end{array}$ & $\begin{array}{c}\text { Export } \\
\text { Brazil }\end{array}$ \\
\hline USD/BRL & 1.000 & -.270 & .165 & .227 & -.048 & .273 & .149 & -.243 & -.356 & -.379 & -.149 & -.375 \\
\hline $\begin{array}{l}\text { Financial } \\
\text { FDI } \\
\text { Brazil }\end{array}$ & -.270 & 1.000 & -.077 & .164 & .261 & -.114 & .113 & .042 & .179 & .033 & .025 & .037 \\
\hline $\begin{array}{l}\text { Income } \\
\text { FDI } \\
\text { Brazil }\end{array}$ & .165 & -.077 & 1.000 & .093 & .093 & -.202 & -.284 & .302 & .223 & .315 & .223 & .351 \\
\hline GPD & .227 & .164 & .093 & 1.000 & .695 & .381 & .248 & -.207 & -.113 & -.330 & .320 & -.146 \\
\hline Inflation & -.048 & .261 & .093 & .695 & 1.000 & .527 & .410 & -.425 & -.342 & -.441 & .417 & -.198 \\
\hline Long & .273 & -.114 & -.202 & .381 & .527 & 1.000 & .858 & -.912 & -.897 & -.863 & -.148 & -.776 \\
\hline Short & .149 & .113 & -.284 & .248 & .410 & .858 & 1.000 & -.904 & -.842 & -.826 & -.392 & -.843 \\
\hline
\end{tabular}




\begin{tabular}{|l|c|c|c|c|c|c|c|c|c|c|c|c|}
\hline $\begin{array}{l}\text { Public } \\
\text { Debt }\end{array}$ & -.243 & .042 & .302 & -.207 & -.425 & -.912 & -.904 & 1.000 & .950 & .925 & .370 & .916 \\
\hline Reserve & -.356 & .179 & .223 & -.113 & -.342 & -.897 & -.842 & .950 & 1.000 & .883 & .370 & .882 \\
\hline $\begin{array}{l}\text { Trade } \\
\text { Balance } \\
\text { Brazil }\end{array}$ & -.379 & .033 & .315 & -.330 & -.441 & -.863 & -.826 & .925 & .883 & 1.000 & .225 & .920 \\
\hline $\begin{array}{l}\text { Import } \\
\text { Brazil }\end{array}$ & -.149 & .025 & .223 & .320 & .417 & -.148 & -.392 & .370 & .370 & .225 & 1.000 & .588 \\
\hline $\begin{array}{l}\text { Export } \\
\text { Brazil }\end{array}$ & -.375 & .037 & .351 & -.146 & -.198 & -.776 & -.843 & .916 & .882 & .920 & .588 & 1.000 \\
\hline
\end{tabular}

Note. The foreign exchange USD/BRL has weak relationship with the macro-economy factors. USD/BRL has a negative relationship with FDI (Financial), Inflation, Public Debt, National Reserve, Trade Balance, Import and Export.

\subsubsection{Macro-economy Determinants to the USD/BRL}

The multiple regression models exclude the trade balance predictor due to its too high VIF and Tolerance. The results from Table 17, 10 variables reflect $77 \%$ the correlation between the USD/BRL exchange rate and the macro-economic factors. The regression model with 10 variables also explains $59.3 \%$ (effect size) of the total variance in USD/BRL exchange rates. The regression model is statistically significant because $\mathrm{p}$-value $<0.05$.

Table 17. Model summary and ANOVA of multiple regression of USD/BRL

\begin{tabular}{|c|c|c|c|c|c|c|c|c|c|}
\hline \multicolumn{4}{|c|}{ Model Summary } & \multicolumn{6}{|c|}{ ANOVA } \\
\hline $\mathbf{R}$ & R Square & $\begin{array}{l}\text { Adjusted } \\
\text { R Square }\end{array}$ & $\begin{array}{l}\text { Std. Error of } \\
\text { the Estimate }\end{array}$ & & $\begin{array}{l}\text { Sum of } \\
\text { Squares }\end{array}$ & df & $\begin{array}{l}\text { Mean } \\
\text { Square }\end{array}$ & $\mathbf{F}$ & Sig. \\
\hline \multirow{3}{*}{$.770^{\mathrm{a}}$} & \multirow{3}{*}{.593} & \multirow{3}{*}{.424} & \multirow{3}{*}{.2078420} & Regression & 1.514 & 10 & .151 & 3.504 & $.006^{\mathrm{b}}$ \\
\hline & & & & Residual & 1.037 & 24 & .043 & & \\
\hline & & & & Total & 2.550 & 34 & & & \\
\hline
\end{tabular}

Note. The multiple regression model with the method ENTER reflected $77 \%$ the correlation between the observed values of the fluctuations of USD/BRL and the values predicted by the model for 10 years in quarterly. Besides, the regression model of 10 variables also explained $59.3 \%$ (effect size) of the total variance of the predictors.

Based on the results from Table 18 and 19, GDP growth rate is statistically significantly positively related to USD/BRL exchange rate, $\beta=0.56, t(33)=2.21, p<0.05$. However, national reserve has a statistically significantly negatively impact on USD/BRL exchange rate, $\beta=-1.23, t(33)=-2.20, p<0.05$. Maximum Cook's distance is 0.84 with a maximum standardized residual of 1.73 (from one subject) suggesting that there is a relatively high level of accuracy of the regression model. 
Table 18. Coefficient result of the multiple regression of USD/BRL

\begin{tabular}{|c|c|c|c|c|c|c|c|c|}
\hline \multicolumn{9}{|c|}{ Coefficients } \\
\hline & \multicolumn{2}{|c|}{ Unstandardized Coefficients } & \multirow{2}{*}{$\begin{array}{c}\text { Standardized } \\
\text { Coefficients }\end{array}$} & \multirow{2}{*}{$\mathbf{t}$} & \multirow{2}{*}{ Sig. } & \multicolumn{3}{|c|}{ Correlations } \\
\hline & B & Std. Error & & & & Zero-order & Partial & Part \\
\hline (Constant) & 2.273 & .973 & & 2.337 & .028 & & & \\
\hline $\begin{array}{l}\text { Financial FDI } \\
\text { Brazil }\end{array}$ & $8.155 \mathrm{E}-06$ & .000 & .030 & .172 & .865 & -.270 & .035 & .022 \\
\hline $\begin{array}{l}\text { Income FDI } \\
\text { Brazil }\end{array}$ & .002 & .001 & .265 & 1.750 & .093 & .165 & .336 & .228 \\
\hline GPD & 5.929 & 2.679 & .557 & 2.213 & .037 & .227 & .412 & .288 \\
\hline Inflation & -10.974 & 5.933 & -.556 & -1.850 & .077 & -.048 & -.353 & -.241 \\
\hline Long & -2.116 & 6.798 & -.156 & -.311 & .758 & .273 & -.063 & -.041 \\
\hline Short & -9.017 & 9.797 & -.336 & -.920 & .366 & .149 & -.185 & -.120 \\
\hline Public Debt & 1.696 & 1.236 & 1.032 & 1.372 & .183 & -.243 & .270 & .179 \\
\hline Reserve & $-9.557 \mathrm{E}-06$ & .000 & -1.232 & -2.190 & .038 & -.356 & -.408 & -.285 \\
\hline Import Brazil & $7.940 \mathrm{E}-05$ & .000 & .325 & 1.310 & .203 & -.149 & .258 & .170 \\
\hline Export Brazil & $-9.348 \mathrm{E}-05$ & .000 & -.952 & -1.775 & .089 & -.375 & -.341 & -.231 \\
\hline
\end{tabular}

Note. A standard multiple regression was conducted to examine the relationship between predictors of macro-economy factors with the outcome USD/BRL in quarterly from 2005 to 2014. The model indicated that GDP and Import significantly predict the outcome: exchange rate USD/BRL ( $\mathrm{p}$-value $<0.05$ ).

Table 19. Residual result of the multiple regression of USD/BRL

\begin{tabular}{|l|r|r|r|r|r|}
\hline \multicolumn{7}{|c|}{ Residuals Statistics } \\
\hline & Minimum & \multicolumn{1}{|c|}{ Maximum } & \multicolumn{1}{c|}{ Mean } & Std. Deviation & N \\
\hline Predicted Value & 1.564037 & 2.411451 & 2.054457 & .2109983 & 35 \\
\hline Std. Predicted Value & -2.324 & 1.692 & .000 & 1.000 & 35 \\
\hline Standard Error of Predicted Value & .078 & .169 & .114 & .024 & 35 \\
\hline Adjusted Predicted Value & 1.534518 & 2.553813 & 2.066836 & .2423713 & 35 \\
\hline Residual & -.3927003 & .3606406 & .0000000 & .1746222 & 35 \\
\hline Std. Residual & -1.889 & 1.735 & .000 & .840 & 35 \\
\hline Stud. Residual & -2.791 & 1.925 & -.023 & 1.046 & 35 \\
\hline Deleted Residual & -.8568132 & .4894379 & -.0123789 & .2771551 & 35 \\
\hline Stud. Deleted Residual & -3.324 & 2.049 & -.037 & 1.128 & 35 \\
\hline Mahal. Distance & 3.846 & 21.637 & 9.714 & 4.544 & 35 \\
\hline Cook's Distance & .000 & .837 & .061 & .148 & 35 \\
\hline Centered Leverage Value & .113 & .636 & .286 & .134 & 35 \\
\hline
\end{tabular}

Note. Maximum Cook's distance was 0.84 with a maximum standardized residual of 1.73 (from one subject) suggesting a relatively high level of accuracy of the regression model. 


\subsubsection{The Effects of the Trade Balance on USD/BRL Exchange Rate}

To examine the influences of the trade balance on USD/BRL exchange rate, the paper uses the multiple regressions with STEPWISE method. The results from Table 21 show that only one model could significantly affect USD/BRL exchange rate and it explains $37.9 \%$ of the correlation between USD/BRL exchange rate and the macro-economic factors. Only $14.4 \%$ of the total variance in USD/BRL exchange can be explained by the macro-economic factors. This model also has p-value of ANOVA $<0.05$ in Table 20. The STEPWISE multiple regression in Table 20 also reveal that the trade balance has a significant impact in USD/BRL exchange rate with the p-value $<0.05$.

Table 20. Model summary and ANOVA of STEPWISE multiple regression of USD/BRL

\begin{tabular}{|c|c|c|c|c|c|c|c|c|c|}
\hline \multicolumn{5}{|c|}{ Model Summary } & \multicolumn{5}{|c|}{ ANOVA } \\
\hline $\mathbf{R}$ & R Square & $\begin{array}{l}\text { Adjusted } \\
\text { R Square }\end{array}$ & $\begin{array}{c}\text { Std. } \\
\text { Error of } \\
\text { the } \\
\text { Estimate }\end{array}$ & & $\begin{array}{l}\text { Sum of } \\
\text { Squares }\end{array}$ & df & $\begin{array}{c}\text { Mean } \\
\text { Square }\end{array}$ & $\mathbf{F}$ & Sig. \\
\hline \multirow{3}{*}{$.379^{\mathrm{a}}$} & \multirow{3}{*}{.144} & \multirow{3}{*}{.118} & \multirow{3}{*}{.2572086} & Regression & .367 & 1 & .367 & 5.552 & $.025^{\mathrm{b}}$ \\
\hline & & & & Residual & 2.183 & 33 & .066 & & \\
\hline & & & & Total & 2.550 & 34 & & & \\
\hline
\end{tabular}

Note. The result of multiple regression with the method STEPWISE indicated only 1 model, which could significantly predict the outcome USD/BRL. These four models could reflect 37.9\% the correlation between the observed values of the outcome USD/BRL, and the values predicted by the model. Moreover, the R Squares (effect size) are $14.4 \%$ of the total variance of the predictors can be explained by the regression model. This model also have p-value of ANOVA significant $(<0.05)$

Table 21. Coefficient result of STEPWISE multiple regression of USD/BRL

\begin{tabular}{|c|c|c|c|c|c|c|c|c|c|}
\hline \multicolumn{10}{|c|}{ Coefficients } \\
\hline & \multirow[t]{2}{*}{ Model } & \multicolumn{2}{|c|}{$\begin{array}{c}\text { Unstandardized } \\
\text { Coefficients }\end{array}$} & \multirow{2}{*}{$\begin{array}{c}\begin{array}{c}\text { Standardized } \\
\text { Coefficients }\end{array} \\
\text { Beta }\end{array}$} & \multirow[t]{2}{*}{$\mathbf{t}$} & \multirow[t]{2}{*}{ Sig. } & \multicolumn{3}{|c|}{ Correlations } \\
\hline & & B & Std. Error & & & & Zero-order & Partial & Part \\
\hline \multirow[b]{2}{*}{1} & (Constant) & 2.121 & .052 & & 40.971 & .000 & & & \\
\hline & $\begin{array}{c}\text { Trade Balance } \\
\text { Brazil }\end{array}$ & $-4.488 \mathrm{E}-05$ & .000 & -.379 & -2.356 & .025 & -.379 & -.379 & -.379 \\
\hline
\end{tabular}

Note. The STEPWISE multiple regression also highlighted the significant prediction and influence of Trade Balance predictor. Especially, the trade balance predictor is significant (p-value $<0.05$ ), which indicated that Trade Balance is also a determinant to the foreign exchange USD/BRL. 


\subsection{Mexico}

The assumption of variables type was met because the outcome USD/MXN and 11 predictors are continuous. The independence of observation was also assumed. The assumption of Non-Zero variance was met because there are standard deviations of the predictors are unequal to 0 . Based on the Figure 4, the assumption of Normally-distributed errors was met. Because the histogram followed the normal distribution and the Normal P-P plot followed a straight line.
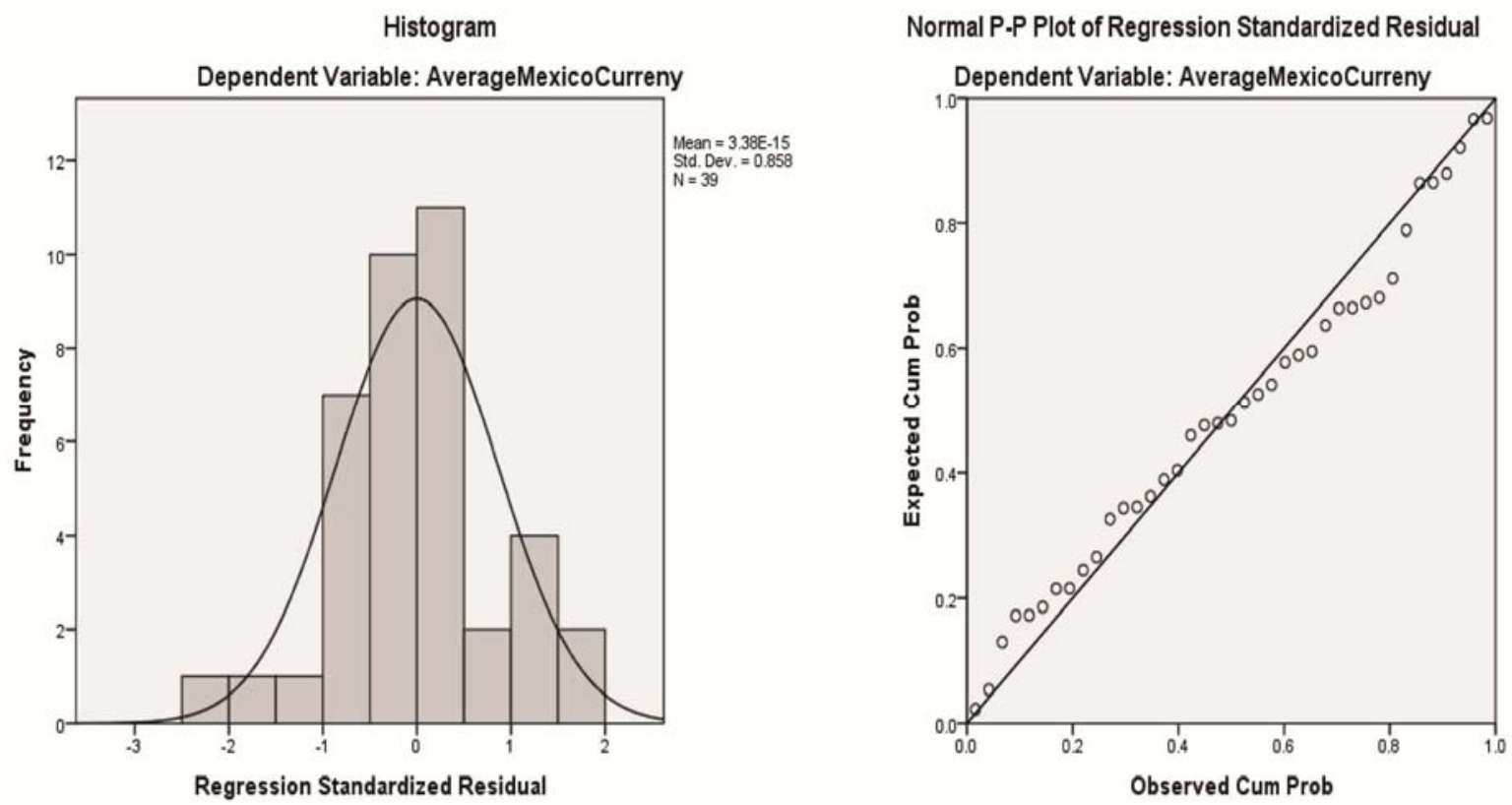

Figure 4. Histogram and normal P-P plot of the outcome USD/MXN

\subsubsection{Relationships among Variables}

Table 22 shows that inflation rate, long-term interest rate, short-term interest rate, public debt and national reserve $(-0.6<\mathrm{x}<0.6)$ have strong correlations with USD/MXN exchange rate. Specifically, inflation rate and interest rate have negative relationships with USD/MXN exchange rate. 
Table 22. Pearson correlations among variables of USD/MXN

\begin{tabular}{|c|c|c|c|c|c|c|c|c|c|c|c|c|}
\hline \multicolumn{13}{|c|}{ Correlations } \\
\hline $\begin{array}{c}\text { Pearson } \\
\text { Correlation }\end{array}$ & $\begin{array}{l}\text { USD/ } \\
\text { MNX }\end{array}$ & $\begin{array}{c}\text { Financial } \\
\text { FDI } \\
\text { Mexico } \\
\end{array}$ & $\begin{array}{c}\text { Income } \\
\text { FDI } \\
\text { Mexico } \\
\end{array}$ & GPD & Inflation & Long & Short & $\begin{array}{c}\text { Public } \\
\text { Debt }\end{array}$ & Reserve & $\begin{array}{c}\text { Trade } \\
\text { Balance } \\
\text { Mexico } \\
\end{array}$ & $\begin{array}{l}\text { Import } \\
\text { Mexico }\end{array}$ & $\begin{array}{l}\text { Export } \\
\text { Mexico }\end{array}$ \\
\hline USD/MNX & 1.000 & .057 & .436 & -.495 & -.719 & -.806 & -.779 & .797 & .705 & .471 & .427 & .542 \\
\hline $\begin{array}{l}\text { Financial FDI } \\
\text { Mexico }\end{array}$ & .057 & 1.000 & .270 & .059 & .005 & -.099 & -.117 & .121 & .133 & -.131 & .184 & .156 \\
\hline $\begin{array}{l}\text { Income FDI } \\
\text { Mexico }\end{array}$ & .436 & .270 & 1.000 & -.025 & -.028 & -.595 & -.662 & .752 & .741 & -.154 & .806 & .781 \\
\hline GPD & -.495 & .059 & -.025 & 1.000 & .605 & .353 & .224 & -.170 & -.082 & -.345 & .190 & .112 \\
\hline Inflation & -.719 & .005 & -.028 & .605 & 1.000 & .496 & .366 & -.435 & -.352 & -.534 & .001 & -.124 \\
\hline Long & -.806 & -.099 & -.595 & .353 & .496 & 1.000 & .859 & -.911 & -.899 & -.372 & -.587 & -.682 \\
\hline Short & -.779 & -.117 & -.662 & .224 & .366 & .859 & 1.000 & -.900 & -.849 & -.286 & -.720 & -.797 \\
\hline Public Debt & .797 & .121 & .752 & -.170 & -.435 & -.911 & -.900 & 1.000 & .955 & .236 & .823 & .890 \\
\hline Reserve & .705 & .133 & .741 & -.082 & -.352 & -.899 & -.849 & .955 & 1.000 & .154 & .788 & .835 \\
\hline $\begin{array}{l}\text { Trade Balance } \\
\text { Mexico } \\
\end{array}$ & .471 & -.131 & -.154 & -.345 & -.534 & -.372 & -.286 & .236 & .154 & 1.000 & -.174 & .057 \\
\hline Import Mexico & .427 & .184 & .806 & .190 & .001 & -.587 & -.720 & .823 & .788 & -.174 & 1.000 & .973 \\
\hline Export Mexico & .542 & .156 & .781 & .112 & -.124 & -.682 & -.797 & .890 & .835 & .057 & .973 & 1.000 \\
\hline
\end{tabular}

Note. The foreign exchange USD/MXN has strong relationship with Inflation rate, Long-term interest rate, Short-term interest rate, Public Debt and National Reserve $(-0.6<\mathrm{x}<0.6)$. USD/MXN also has a negative relationship with GDP, Inflation and Interest Rate (Long and Short).

\subsubsection{Macro-economy Determinants to the USD/MXN}

The multiple regression equation excludes the import due to its too high VIF and Tolerance. According to Table 23, the model explains $87.6 \%$ (effect size) of the total variance in $\mathrm{USD} / \mathrm{MXN}$ exchange rate. The model is statistically significant with p-value $=0(<0.001)$.

Table 23. Model summary and ANOVA of multiple regression of USD/MXN

\begin{tabular}{|c|c|c|c|c|c|c|c|c|c|}
\hline \multicolumn{4}{|c|}{ Model Summary } & \multicolumn{6}{|c|}{ ANOVA } \\
\hline $\mathbf{R}$ & $\begin{array}{c}\mathbf{R} \\
\text { Square }\end{array}$ & $\begin{array}{c}\text { Adjusted R } \\
\text { Square }\end{array}$ & $\begin{array}{c}\text { Std. Error of the } \\
\text { Estimate }\end{array}$ & & $\begin{array}{l}\text { Sum of } \\
\text { Squares }\end{array}$ & df & $\begin{array}{l}\text { Mean } \\
\text { Square }\end{array}$ & $\mathbf{F}$ & Sig. \\
\hline \multirow{3}{*}{$.936^{\mathrm{a}}$} & \multirow{3}{*}{.876} & \multirow{3}{*}{.831} & \multirow{3}{*}{.4648864} & Regression & 42.686 & 10 & 4.269 & 19.751 & $.000^{\mathrm{b}}$ \\
\hline & & & & Residual & 6.051 & 28 & .216 & & \\
\hline & & & & Total & 48.737 & 38 & & & \\
\hline
\end{tabular}

Note. The multiple regression model with the method ENTER reflected $93.6 \%$ the correlation between the observed values of the fluctuations of USD/MXN and the values predicted by the model for 10 years in quarterly. Besides, the regression model of 10 variables also explained $87.6 \%$ (effect size) of the total variance of the predictors.

From Table 24, public debt and export have a statistically significant impact USD/MXN exchange rate with $\mathrm{p}$-value $<0.05$. Public debt is statistically significantly positively related to $\mathrm{USD} / \mathrm{MXN}$ exchange rate, $\beta=1.63, \mathrm{t}(37)=2.84, \mathrm{p}<0.05$. Export has statistically 
significantly negatively impact USD/MXN exchange rate, $\beta=-0.60, \mathrm{t}(37)=-2.16, \mathrm{p}<0.05$. Maximum Cook's distance is 0.30 with a maximum standardized residual of 2.07 (from one subject) suggesting that there is a relatively high level of accuracy in the regression model.

Table 24. Coefficient result of the multiple regression of USD/MXN

\begin{tabular}{|c|c|c|c|c|c|c|c|c|}
\hline \multicolumn{9}{|c|}{ Coefficients } \\
\hline & \multicolumn{2}{|c|}{$\begin{array}{l}\text { Unstandardized } \\
\text { Coefficients }\end{array}$} & \multirow{2}{*}{$\begin{array}{c}\begin{array}{c}\text { Standardized } \\
\text { Coefficients }\end{array} \\
\text { Beta } \\
\end{array}$} & \multirow[t]{2}{*}{$\mathbf{t}$} & \multirow{2}{*}{ Sig. } & \multicolumn{3}{|c|}{ Correlations } \\
\hline & B & Std. Error & & & & Zero-order & Partial & Part \\
\hline (Constant) & 8.809 & 2.416 & & 3.646 & .001 & & & \\
\hline FinancialMexico & $3.879 \mathrm{E}-05$ & .000 & .037 & .515 & .611 & .057 & .097 & .034 \\
\hline IncomeMexico & .000 & .001 & -.099 & -.692 & .495 & .436 & -.130 & -.046 \\
\hline GPD & -6.128 & 5.327 & -.130 & -1.150 & .260 & -.495 & -.212 & -.077 \\
\hline Inflation & -10.553 & 11.521 & -.132 & -.916 & .367 & -.719 & -.171 & -.061 \\
\hline Long & 19.865 & 16.245 & .362 & 1.223 & .232 & -.806 & .225 & .081 \\
\hline Short & -33.306 & 18.534 & -.297 & -1.797 & .083 & -.779 & -.322 & -.120 \\
\hline PublicDebt & 10.994 & 3.876 & 1.630 & 2.837 & .008 & .797 & .472 & .189 \\
\hline Reserve & $-9.047 \mathrm{E}-06$ & .000 & -.284 & -.988 & .332 & .705 & -.184 & -.066 \\
\hline BalanceMexico & $3.929 \mathrm{E}-05$ & .000 & .088 & .939 & .356 & .471 & .175 & .063 \\
\hline ExportMexico & $-6.192 \mathrm{E}-05$ & .000 & -.596 & -2.157 & .040 & .542 & -.377 & -.144 \\
\hline
\end{tabular}

Note. A standard multiple regression was conducted to examine the relationship between predictors of macro-economy factors with the outcome USD/MXN in quarterly from 2005 to 2014. The model indicated that Public Debt and Export significantly predict the outcome: exchange rate USD/MXN (p-value $<0.05$ ).

Table 25. Residual result of the multiple regression of USD/MXN

\begin{tabular}{|l|c|c|c|c|c|}
\hline \multicolumn{7}{|c|}{ Residuals Statistics } \\
\hline & Minimum & Maximum & Mean & Std. Deviation & N \\
\hline Predicted Value & 10.534721 & 13.846875 & 12.208577 & 1.0598636 & 39 \\
\hline Std. Predicted Value & -1.579 & 1.546 & .000 & 1.000 & 39 \\
\hline Standard Error of Predicted Value & .151 & .389 & .241 & .055 & 39 \\
\hline Adjusted Predicted Value & 10.349805 & 14.228850 & 12.212921 & 1.0515243 & 39 \\
\hline Residual & -.9325971 & .8615537 & .0000000 & .3990562 & 39 \\
\hline Std. Residual & -2.006 & 1.853 & .000 & .858 & 39 \\
\hline Stud. Residual & -2.333 & 2.070 & -.003 & 1.011 & 39 \\
\hline Deleted Residual & -1.2612948 & 1.1340175 & -.0043436 & .5659148 & 39 \\
\hline Stud. Deleted Residual & -2.552 & 2.209 & -.001 & 1.049 & 39 \\
\hline Mahal. Distance & 3.056 & 25.571 & 9.744 & 5.170 & 39 \\
\hline Cook's Distance & .000 & .296 & .041 & .064 & 39 \\
\hline Centered Leverage Value & .080 & .673 & .256 & .136 & 39 \\
\hline
\end{tabular}

Note. Maximum Cook's distance was 0.30 with a maximum standardized residual of 2.07 (from one subject) suggesting a relatively high level of accuracy of the regression model.

\subsubsection{The Effects of the Import USD/MXN Exchange Rate}

To investigate the impact of the import in USD/MXN exchange rate, the paper implements the multiple regressions with STEPWISE method. The results from Table 26 four multiple regression models could statistically significantly predict USD/MNX exchange rate. These 
models could reflect up to more than $80.6 \%$ the correlation between USD/MXN exchange rate and the macro-economic factors. In addition, $64.9 \%$ of the total variance in USD/MXN exchange rate can be explained by the macro-economic factors. This model also has p-values of ANOVA in Table $27=0(<0.001)$. The STEPWISE multiple regressions in Table 27 the import is not a determinant of USD/MXN exchange rate fluctuations.

Table 26. Model summary of STEPWISE multiple regression of USD/MNX

\begin{tabular}{|c|c|c|c|c|}
\hline \multicolumn{3}{|c|}{ Model Summary } \\
\hline Model & R & R Square & Adjusted R Square & Std. Error of the Estimate \\
\hline $\mathbf{1}$ & $.806^{\mathrm{a}}$ & .649 & .639 & .6800452 \\
\hline $\mathbf{2}$ & $.886^{\mathrm{b}}$ & .784 & .772 & .5403391 \\
\hline $\mathbf{3}$ & $.913^{\mathrm{c}}$ & .834 & .819 & .4812739 \\
\hline $\mathbf{4}$ & $.908^{\mathrm{d}}$ & .825 & .815 & .4873709 \\
\hline
\end{tabular}

Note. The result of multiple regression with the method STEPWISE indicated 4 models, which could significantly predict the outcome USD/MNX. These four models could reflect up to more than $80.6 \%$ the correlation between the observed values of the outcome USD/MNX, and the values predicted by the model. Moreover, the R Squares (effect size) are more than $64.9 \%$ of the total variance of the predictors can be explained by the regression model.

Table 27. ANOVA of STEPWISE multiple regression of USD/MNX

\begin{tabular}{|c|c|c|c|c|c|c|}
\hline \multicolumn{7}{|c|}{ ANOVA } \\
\hline & Model & Sum of Squares & df & Mean Square & $\mathbf{F}$ & Sig. \\
\hline \multirow{3}{*}{1} & Regression & 31.626 & 1 & 31.626 & 68.386 & $.000^{\mathrm{b}}$ \\
\hline & Residual & 17.111 & 37 & .462 & & \\
\hline & Total & 48.737 & 38 & & & \\
\hline \multirow{3}{*}{2} & Regression & 38.226 & 2 & 19.113 & 65.464 & $.000^{\mathrm{c}}$ \\
\hline & Residual & 10.511 & 36 & .292 & & \\
\hline & Total & 48.737 & 38 & & & \\
\hline \multirow{3}{*}{3} & Regression & 40.630 & 3 & 13.543 & 58.471 & $.000^{\mathrm{d}}$ \\
\hline & Residual & 8.107 & 35 & .232 & & \\
\hline & Total & 48.737 & 38 & & & \\
\hline \multirow{3}{*}{4} & Regression & 40.186 & 2 & 20.093 & 84.591 & $.000^{\mathrm{e}}$ \\
\hline & Residual & 8.551 & 36 & .238 & & \\
\hline & Total & 48.737 & 38 & & & \\
\hline
\end{tabular}

Note. These model also have $\mathrm{p}$-values of ANOVA equal to 0 ( $\mathrm{p}$-value $<0.001$ ). 
Table 28. Coefficient result of STEPWISE multiple regression of USD/MNX

\begin{tabular}{|c|c|c|c|c|c|c|c|c|c|}
\hline \multicolumn{10}{|c|}{ Coefficients } \\
\hline & \multirow{2}{*}{ Model } & \multicolumn{2}{|c|}{$\begin{array}{c}\text { Unstandardized } \\
\text { Coefficients }\end{array}$} & \multirow{2}{*}{$\begin{array}{c}\text { Standardized } \\
\text { Coefficients }\end{array}$} & \multirow{2}{*}{ t } & \multirow{2}{*}{ Sig. } & \multicolumn{3}{|c|}{ Correlations } \\
\hline & & B & Std. Error & & & & Zero-order & Partial & Part \\
\hline \multirow{2}{*}{1} & (Constant) & 13.006 & .145 & & 89.414 & .000 & & & \\
\hline & Long & -44.260 & 5.352 & -.806 & -8.270 & .000 & -.806 & -.806 & -.806 \\
\hline \multirow{3}{*}{2} & (Constant) & 13.565 & .165 & & 82.282 & .000 & & & \\
\hline & Long & -32.697 & 4.899 & -.595 & -6.674 & .000 & -.806 & -.744 & -.517 \\
\hline & Inflation & -33.971 & 7.145 & -.424 & -4.755 & .000 & -.719 & -.621 & -.368 \\
\hline \multirow{4}{*}{3} & (Constant) & 14.860 & .428 & & 34.726 & .000 & & & \\
\hline & Long & -11.084 & 8.003 & -.202 & -1.385 & .017 & -.806 & -.228 & -.095 \\
\hline & Inflation & -36.766 & 6.423 & -.459 & -5.724 & .000 & -.719 & -.695 & -.395 \\
\hline & Short & -49.080 & 15.235 & -.438 & -3.222 & .003 & -.779 & -.478 & -.222 \\
\hline \multirow{3}{*}{4} & (Constant) & 15.321 & .272 & & 56.291 & .000 & & & \\
\hline & Inflation & -40.159 & 6.012 & -.501 & -6.679 & .000 & -.719 & -.744 & -.466 \\
\hline & Short & -66.767 & 8.411 & -.596 & -7.938 & .000 & -.779 & -.798 & -.554 \\
\hline
\end{tabular}

Note. The STEPWISE multiple regression also highlighted the significant predictions and influences of Long-term, Short-term Interest Rate and Inflation. Especially, the import predictor is not significant, interest rate and inflation are significant for 4 models with the high contribution. It means that the interest rate and inflation are also determinants to the fluctuations of the foreign exchange USD/MNX.

\section{Conclusion}

This study examines the impact of macro-economic factors on the foreign exchange rates between USA and four big emerging countries, India, Mexico, Brazil and China for the period of 2005 to 2014 by using Enter and Stepwise multiple regression methods.

The multiple regression results with the type I error to examine determinants of USD/CNY, USC/INR, USD/BRL and USD/MNX exchange rates from January 2005 to December 2014. The results reveal that GDP, inflation, public debt and international trade have statistically significant impact USD/CNY exchange rate and ENTER method suggests that $98 \%$ of total variances in USD/CNY exchange rate can be explained by the macro-economic factors. STEPWISE method suggests 4 significant models.

On the other hand, financial FDI, public debt, national reserve, trade balance and inflation statistically significant effect on USD/INR exchange rate and ENTER method reveal that $86.2 \%$ of variances in USD/INR exchange rate can be explained by the macro-economic factors.

GDP growth rate, national reserve and trade balance statistically significant impact on USD/BRL exchange rate. The macro-economic factors explain the $59.3 \%$ of total variance in USD/BRL exchange rate. STEPWISE method suggests only one significant model. Lastly, public debt, export, interest rate (Long and Short) and inflation have statistically significant 
impact in USD/MNX exchange rate. ENTER method reveal that $87.6 \%$ of total variance in USD/MXN can be explained by the macro-economic factors. STEPWISE method suggests 4 significant models. All of the ANOVA results with the type I error as 0.05 are significant with $\mathrm{p}$-values $<0.05$. Therefore, it is crucial to emphasize that the macroeconomic policies have to be implemented in order to stabilize and reduce the exchange rates volatilities.

An interesting extension of this research would be to study the impact of the macro-economic factors on the different countries. In addition, the impact of other macro-economic factors on exchange rates can be examined. This question, though intriguing, is left for future research.

\section{References}

Akram, M., Sajjad, H., Fatima, T., Mukhtar, S., \& Alam, H. M. (2011). Contagious Effects of Greece Crisis on Euro-Zone States. International Journal of Business and Social Science, 2(12), [Online] Available: http://www.ijbssnet.com/journals/Vol.2No.12\%3BJuly2011/14.pdf

Alicia, G. H., \& Koivu, T. (2009). China: Exchange Rate Policy and Asian Trade (No. 0916). BBVA Bank, Economic Research Department. [Online] Available: http://www.bis.org/publ/work282.pdf

Avery, R. B., Elliehausen, G. E., Kennickell, A. B., \& Spindt, P. A. (1987). Changes in the Use of Transaction Accounts and Cash from 1984 to 1986. Fed. Res. Bull., 73, 179. [Online] Available:

http://heinonline.org/HOL/LandingPage?handle=hein.journals/fedred73\&div=37\&id=\&page

Bahmani-Oskooee, M., \& Hegerty, S. W. (2009). The effects of exchange-rate volatility on commodity trade between the United States and Mexico. Southern Economic Journal, 1019-1044. [Online] Available: http://www.jstor.org/stable/27751431

Bahmani-Oskooee, M., Harvey, H., \& Hegerty, S. W. (2013). The effects of exchange-rate volatility on commodity trade between the US and Brazil. The North American Journal of Economics and Finance, 25, 70-93. http://dx.doi.org/10.1016/j.najef.2013.03.002

Bergsten, C. F. (1997). The impact of the euro on exchange rates and international policy cooperation. EMU and the international monetary system, 17-48.

Blankfeld, K. (2010). Is Brazil's Economy Getting Too Hot. Forbes Magazine. [Online] Available:

http://www.forbes.com/sites/kerenblankfeld/2010/12/13/-is-brazils-economy-getting-too-hot/

Bracke, T., \& Bunda, I. (June 3, 2011). Bracke, Thierry and Bunda, Irina, Exchange Rate Anchoring - Is there Still a De Facto US Dollar Standard? ECB Working Paper No. 1353. [Online] Available: http://ssrn.com/abstract=1857395

Campa, J. M., Chang, P. K., \& Refalo, J. F. (2002). An options-based analysis of emerging market exchange rate expectations: Brazil's Real Plan, 1994-1999. Journal of Development Economics, 69(1), 227-253. http://dx.doi.org/10.1016/S0304-3878(02)00060-3 
Chen, H., Peng, W., \& Shu, C. (2009). The potential of the Renminbi as an international currency. BIS Asian Research Program Research Papers.

Chinn, M., \& Frankel, J. A. (2007). Will the euro eventually surpass the dollar as leading international reserve currency? In G7 Current account imbalances: sustainability and adjustment (pp. 283-338). University of Chicago Press. http://dx.doi.org/10.7208/chicago/9780226107288.003.0009

Chunwei, Z. (2008). Dollar Standard, Dollar Circumfluence and Dollar Trap [J]. Studies of International Finance, 6(1). [Online] Available: http://en.cnki.com.cn/Article_en/CJFDTOTAL-GJJR200806001.htm

Cohen, B. J. (2012). The future of global currency: the euro versus the dollar. Routledge.

Conerly, B. (2013). Future of the Dollar as World Reserve Currency. Forbes Business. [Online]

Available: http://www.forbes.com/sites/billconerly/2013/10/25/future-of-the-dollar-as-world-reserve-cur rency/

Devereux, M. B., Shi, K., \& Xu, J. (2007). Global monetary policy under a dollar standard. $\begin{array}{llll}\text { Journal of International } & \text { Economics, } & 71(1), & 132 .\end{array}$ http://dx.doi.org/10.1016/j.jinteco.2005.12.007

Dooley, M. (2005). International financial stability: Asia, interest rates, and the dollar. Deutsche Bank AG. [Online] Available: http://people.ucsc.edu/ mpd/-InternationalFinancialStability_update.pdf.

Dooley, M. P., Folkerts - Landau, D., \& Garber, P. (2004). The revived Bretton Woods system. International Journal of Finance \& Economics, 9(4), 307-313. http://dx.doi.org/10.1002/ijfe.250

Ehrmann, M., Fratzscher, M., \& Rigobon, R. (2011). Stocks, bonds, money markets and exchange rates: measuring international financial transmission. Journal of Applied Econometrics, 26(6), 948-974. http://dx.doi.org/10.1002/jae.1173

Eichengreen, B. (1998). The euro as a reserve currency. Journal of the Japanese and International Economies, 12(4), 483-506. http://dx.doi.org/10.1006/jjie.1998.0411

Eichengreen, B. (2011). The Renminbi as an international currency. Journal of Policy Modeling, 33(5), 723-730. http://dx.doi.org/10.1016/j.jpolmod.2011.07.004

Eichengreen, B. J. (2000). International monetary arrangements for the 21st century. Brookings Institution Press. [Online] Available: http://www.jstor.org/stable/2729231

Feige, E. L. (1996). Overseas holdings of US currency and the underground economy. Exploring the Underground Economy. Kalamazoo, Michigan, 5-62. http://dx.doi.org/10.17848/9780880994279.ch2

Felisoni de Angelo, C., Eunni, R. V., \& Manoel Martins Dias Fouto, N. (2010). Determinants of FDI in emerging markets: evidence from Brazil. International Journal of Commerce and 
Management, 20(3), 203-216. http://dx.doi.org/10.1108/10569211011076901

Figueroa, A., Lee, E. \& Schoik, R. V. (2011). Realizing the Full Value of Cross border Trade with Mexico. ASU North American Center for Transborder Studies. [Online] Available: https://21 stcenturyborder.files.wordpress.com/2011/12/realizing-the-value-of-crossborder-tra de-with-mexico2.pdf

Gaspar, V. (2004). Financial integration and the international role of the euro. Remarks made at "Euro at Five: Ready for a Global Role", Institute for International Economics, Washington, DC, 26. [Online] Available: http://www.iie.com/publications/papers/gaspar0204.pdf

Genberg, H., \& Swoboda, A. K. (1977). Worldwide inflation under the dollar standard. Institut universitaire de hautes études internationales.

Goldstein, M., \& Lardy, N. (2009). The future of China's exchange rate policy. Peterson Institute.

Goyal, A. (2012). Evolution of India's exchange rate regime. Indira Gandhi Institute of Development Research, Mumbai. [Online] Available: http://hdl.handle.net/2275/128

Goyal, A., \& Arora, S. (2010). The Indian Exchange Rate and Central Bank Action: A GARCH Analysis. Indira Gandhi Institute of Development Research. Mumbai Working Paper 2010-009. [Online] Available: http://www.igidr.ac.in/pdf/publication/WP-2010-009.pdf

Greenspan, A. (2001). The euro as an international currency. Remarks before the "Euro", 50. [Online] Available: http://www.federalreserve.gov/boardDocs/speeches/-2001/200111302/default.htm

Haberler, G. (1972). Prospects for the dollar standard. American Enterprise Institute.

Halligan, L. (2014). The dollar's 70-year dominance is coming to an end. The telegraph. [Online]

Available: http://www.telegraph.co.uk/finance/comment/liamhalligan/10978178/-The-dollars-70-year-do minance-is-coming-to-an-end.html

Hartmann, P. (1996). The future of the euro as an international currency: a transactions perspective (No. sp91). Financial Markets Group. [Online] Available: http://www.lse.ac.uk/fmg/documents/specialPapers/1990s/sp91.pdf

Ibarra, C. A. (2011). Capital flows and real exchange rate appreciation in Mexico. World Development, 39(12), 2080-2090. http://dx.doi.org/10.1016/j.worlddev.2011.05.020

Jaeger, M., Lanzeni, M. L., \& Mayer, T. (2010). Yuan as a reserve currency. Frankfurt am Main: Detsche Bank Research. [Online] Available: http://www.dbresearch.eu/PROD/DBR_INTERNET_EN-PROD/PROD0000000000260162.P DF

Joshi, S., Mohan, C. R., Sood, V., Rajagopalam, R. P., Carafano, J. J., Lohman, W., ... \& Scissors, D. (2013). Beyond the Plateau in US-India Relations. Heritage Foundation, April, 26. 
http://www.heritage.org/research/reports/2013/04/beyond-the-plateau-in-us-india-relations

Kaltenbrunner, A. (2010). International financialization and depreciation: the Brazilian real in the international financial crisis. Competition \& Change, 14(3-4), 296-323. http://dx.doi.org/10.1179/102452910X12837703615454

Kaltenbrunner, A. (2011). Currency internationalisation and exchange rate dynamics in emerging markets: a post Keynesian analysis of Brazil (Doctoral dissertation, SOAS, University of [Online] Available: https://core.ac.uk/download/files/103/9550602.pdf

Kellner, I. (2015). Opinion: Slowing U.S. economy is inconvenient truth. MarketWatch. Retrieve from http://www.marketwatch.com/story/slowing-us-economy-is-inconvenient-truth-2015-03-03

Krugman, P. R. (1984). The international role of the dollar: theory and prospect. In Exchange rate theory and practice (pp. 261-278). University of Chicago press. [Online] Available: http://www.nber.org/chapters/c6838.pdf

Kubarych, R. M. (1983). Foreign exchange markets in the United States. Federal Reserve Bank of New York.

Kumar, S. (2010). Determinants of Real Exchange Rate in India: An ARDL Approach. Reserve Bank of India Occasional Papers, 31(1), 33-64. [Online] Available: https://www.rbi.org.in/scripts/bs_viewcontent.aspx?Id=2247

Kutty, G. (2010). The relationship between exchange rates and stock prices: the case of Mexico. North American Journal of Finance and Banking Research, 4(4). [Online] Available: http:/globip.com/articles/northamerjournal-vol4-article1.pdf

Laurent, R. D. (1974). Currency in Circulation and the Real Value of Notes. Journal of Money, Credit and Banking, 213-226. http://dx.doi.org/10.2307/1991026

Lee, E., \& Wilson, C. E. (2012). The State of Trade, Competitiveness and Economic Well-being in the U.S.-Mexico Border Region. Working Paper Series on the State of the U.S.-Mexico Border. [Online] Available: http://kpbs.media.clients.ellingtoncms.com/news/documents/2012/06/06/State_of_Border_Tr ade_Economy.pdf

Lee, J. W. (2014). Will the Renminbi Emerge as an International Reserve Currency? The World Economy, 37(1), 42-62. http://dx.doi.org/10.1111/twec.12092

Lin, C. H. (2011). Exchange rate exposure in the Asian emerging markets. Journal of multinational financial Management, 224-238. http://dx.doi.org/10.1016/j.mulfin.2011.04.002

López Villavicencio, A., \& Raymond Bara, J. L. (2008). Short - run and long - run determinants of the real exchange rate in Mexico. The Developing Economies, 46(1), 52-74. http://dx.doi.org/10.1111/j.1746-1049.2007.00055.x 
Loría, E., Sánchez, A., \& Salgado, U. (2010). New evidence on the monetary approach of exchange rate determination in Mexico 1994-2007: a cointegrated SVAR model. Journal of International Money and Finance, 29(3), 540-554. http://dx.doi.org/10.1016/j.jimonfin.2009.07.007

McKinnon, R., \& Schnabl, G. (2003). The East Asian dollar standard, fear of floating, and original sin.

McMichael, P. (1996). Globalization: Myths and Realities. Rural Sociology, 61(1), 25-55. http://dx.doi.org/10.1111/j.1549-0831.1996.tb00609.x

Mirchandani, A. (2012). Analysis of macroeconomic determinants of exchange rate volatility in India. International Journal of Economics and Financial Issues, 3(1), 172-179. [Online] Available: http://www.econjournals.com/index.php/ijefi/article/view/349/pdf

Moreira, C. A., Prates, M. D., \& Ferrari-Filho, F. (2011). Brazil responses to the international financial crisis: A successful example of Keynesian policies? Panoeconomicus, 58(5), 693-714. http://dx.doi.org/10.2298/PAN1105693M

Morgan, J. P. (2009). Questioning the US Dollar's Status as a Reserve Currency. JP Morgan Asset Management-Insights.

Morrison, W. M. (2009). China's economic conditions. Library of Congress Washington Dc Congressional Research [Online] Available: http://fpc.state.gov/documents/organization/194783.pdf

Moura, M. L., Lima, A. R., \& Mendonça, R. M. (2008). Exchange rate and fundamentals: the case of Brazil. Economia Aplicada, 12(3), 395-416. [Online] Available: http://www.scielo.br/scielo.php?pid=S1413-80502008000300003\&script=sci_arttext

Nassif, A., Feijó, C., \& Araújo, E. (2011). The Long-Term “Optimal” Real Exchange Rate and the Currency Overvaluation Trend in Open Emerging Economies: The Case of Brazil (No. 206). United Nations Conference on Trade and Development. [Online] Available: http://daadpartnership.htw-berlin.de/fileadmin/Workshops/2011_Campinas/Papers/NASSIF_ FEIJO_AND_ARAUJO_Optimal_RER_09.2011.pdf

Ogawa, E., \& Sakane, M. (2006). The Chinese Yuan after the Chinese Exchange Rate System Re-form. China and World Economy, 14, 39-57. China \& World Economy in 2006. http://dx.doi.org/10.1111/j.1749-124X.2006.00044.x

Orphanides, A., \& Porter, R. D. (2000). P* revisited: Money-based inflation forecasts with a changing equilibrium velocity. Journal of Economics and Business, 52(1), 87-100. http://dx.doi.org/10.1016/S0148-6195(99)00028-4

Papaioannou, E., Portes, R., \& Siourounis, G. (2006). Optimal currency shares in international reserves: the impact of the euro and the prospects for the dollar. Journal of the Japanese and International Economies, 20(4), 508-547. http://dx.doi.org/10.1016/j.jjie.2006.07.002 
Patnaik, I. (2004). India's experience with a pegged exchange rate. In The India Policy Forum (pp. 189-226).

Porter, R. D., \& Judson, R. A. (1996). Location of US Currency: How Much Is Abroad. Fed. Res. Bull., 82, 883.

Rangarajan, C., \& Mishra, P. (2013). India's External Sector. Economic \& Political Weekly, 48(7), 53.5 [Online] Available: http://www.prachimishra.net/IN-C\%20Rangarajan-Prachi_Mishra.pdf

Rangarajan, C., \& Prasad, A. (2008). Capital flows, exchange rate management and monetary policy. Macroeconomics and Finance in Emerging Market Economies, 1(1), 135-149. http://dx.doi.org/10.1080/17520840701859534

Ranjan, R., \& Prakash, A. (2010). Internationalization of currency: the case of the Indian Rupee and Chinese Renminbi. RBI Staff Studies, 3, 2010. [Online] Available: http://citeseerx.ist.psu.edu/viewdoc/download?doi=10.1.1.182.3811\&rep=rep1\&type=pdf

Ross, M. H. (1983). Currency substitution and instability in the world dollar standard: comment. American Economic Review, 73(3). [Online] Available: http://www.jstor.org/stable/-579

Santos, A. (2012). Carving Out Policy Autonomy for Developing Countries in the World Trade Organization: The Experience of Brazil and Mexico. Virginia Journal of International Law, 52(3).

Schinasi, M. G. J., \& Prati, M. A. (1997). European monetary union and international capital markets: structural implications and risks. International Monetary Fund. http://dx.doi.org/10.5089/9781451848250.001

Shylajan, C. S., Sreejesh, S., \& Suresh, K. G. (2011). Rupee-dollar exchange rate and macroeconomic fundamentals: an empirical analysis using flexible-price monetary model. Journal of International Business and Economy, 12(2), 89-105. [Online] Available: http://www.i-jibe.org/achive/2011fall/2011_12(2)_5.pdf

Sidaoui, J., Ramos-Francia, M., \& Cuadra, G. (2010). The global financial crisis and policy response in Mexico. BIS Papers No, 54, 279-298. [Online] Available: http://ssrn.com/abstract $=1959828$

Stone, M., Walker, W. C., \& Yasui, Y. (2009). From Lombard Street to Avenida Paulista: Foreign Exchange Liquidity Easing in Brazil in Response to the Global Shock of 2008-2009. IMF Working Papers, 1-35.

Sweeney, P., \& Jianxin, L. (2015). China lets yuan fall further, fuels fears of "currency war". Thomson Reuters. [Online] Available: http://www.reuters.com/article/2015/08/12/us-china-markets-yuan-idUSKCN0QG04U20150 812

Tabak, B. M. (2006). The dynamic relationship between stock prices and exchange rates: 
Evidence for Brazil. International Journal of Theoretical and Applied Finance, 9(8), 1377-1396. http://dx.doi.org/10.1142/S0219024906003974

Van Agtmael, A. (2012). Think again: the BRICS. Foreign Policy, 196, 76. [Online] Available: http://crawl.prod.proquest.com.s3.amazonaws.com/fpcache/5f2b4d53d3da5151f6e6f9d91ad6 $3 \mathrm{fb} 4 . p d f$ ?AWSAccessKeyId=AKIAJF7V7KNV2KKY2NUQ\&Expires=1457997998\&Signat ure $=$ WRr1NxCHkTh6IJG2Ho5s7\%2BuYyrI\%3D

Villareal, M. A. (2015). US-Mexico Economic Relations: Trends, Issues, and Implications. Congressional Research Service.

Williamson, J. (2010). Exchange Rate Policy in Brazil. Peterson Institute for International Economics Working Paper, (10-16). http://dx.doi.org/10.2139/ssrn.1718601

Wilson, C. E. (2011). Working together: Economic ties between the United States and Mexico. Woodrow Wilson International Center for Scholars. [Online] Available: https://www.wilsoncenter.org/sites/default/files/Working\%20Together\%20Full\%20Document .pdf

\section{Copyright Disclaimer}

Copyright for this article is retained by the author(s), with first publication rights granted to the journal.

This is an open-access article distributed under the terms and conditions of the Creative Commons Attribution license (http://creativecommons.org/licenses/by/3.0/). 